\title{
NATURE, AFFINITIES AND SIGNIFICANCE OF METAVOLCANIC ROCKS IN THE OUTOKUMPU ASSEMBLAGE, EASTERN FINLAND
}

\author{
ADRIAN F. PARK
}

PARK, A.F., 1983: Nature, affinities and significance of metavolcanic rocks in the Outokumpu assemblage, eastern Finland. Bull. Geol. Soc. Finland 56, Part $1-2,25-52$.

The rock association of serpentinite-chrome-silicate skarn-dolomitequartz rock-black schist in the Outokumpu region, in which polymetallic sulphide ore deposits occur, has been compared to an ophiolite. However, despite evidence that the orebodies have a sea-floor exhalative origin, volcanogenic rocks have only been described recently. Evidence is now presented that, in the Losomäki district, the volcanogenic rocks include pillow lavas, vesicular lava, agglomerate and tuff with autoclastic breccia. These original features indicative of a volcanogenic derivation are restricted to low strain enclaves in amphibole-chlorite $( \pm$ garnet) schists, amphibole-epidote schists, zoisite-amphibole ( \pm chlorite) rocks and hornblende-plagioclase-quartz rocks, previously mapped as »skarn». These banded amphibolites and greenschists show evidence of repeated deformation and recrystallisation under $\mathrm{P}-\mathrm{T}$ conditions pertaining successively to amphibolite and greenschist facies conditions, and grade into rocks retaining distinctive volcanogenic features. At Losomäki they constitute about $30 \%$ of the outcrop of the serpentinite-skarn-dolomite-quartz rock - black schist assemblage, referred to as the Outokumpu assemblage. Comparable rocks occur in the same assemblage elsewhere in the Outokumpu region.

Even though original volcanogenic features survive, complete metamorphic reconstitution means that the original compositions have to be deduced. Possible pseudomorphs after skeletal olivine (?spinifex) occur in some pillow cores, suggesting komatiitic affinities. Whole-rock chemistry indicates extensive alteration before the first metamorphic reconstitution; leaching of alkalis, iron, nickel, cobalt, chromium and base metals is implied, presumably in a marine environment. Some trace element ratios appear to remain well constrained, particularly $\mathrm{Ti}: \mathrm{Zr}, \mathrm{Zr}: \mathrm{Y}$ and Ti:Y. On discriminant function diagrams affinities are suggested with primitive tholeiites of island arcs or back-arc basins; other features suggest similarities to the komatiite-tholeiite association of Archaean greenstone belts.

The environment of eruption, as indicated by the relict morphology and field relations of the pillow lavas and related volcanoclastic deposits, appears to have been under shallow water on the seafloor. The geochemical parameters suggest that the tectonic setting was in an island-arc or back-arc basin and not on the deep ocean floor.

Key words: metavolcanic rocks, Outokumpu.

Adrian F. Park: Department of Applied Geology, University of Strathclyde, Glasgow, G1 1xJ, Scotland, U.K. 


\section{Introduction}

The existence of a volcanogenic component in the rock association of serpentinite-skarndolomite-quartz rock, the serpentinitequartzite-ore association of Gaál et al. (1975) and the Outokumpu association of Huhma (1976), appears to have been in the mind of many workers on the rocks of the Outokumpu region since Wegmann (1928). It is implicit in the use of "ophiolite» or "ophiolite suite» ( $c f$. Wegmann 1928; Väyrynen 1939; Huhma 1975; Campbell 1978; Bowes 1980; Bowes and Gaál 1981). It is also consistent with the interpretation of the $\mathrm{Cu}-\mathrm{Co}-\mathrm{Zn}$ ores of the region as stratabound, marine, exhalative deposits (Böchert 1954; Mäkelä 1974; Koistinen 1981). However, apart from a tentative identification of spinifex textures in the main ultramafic bodies (Mutanen 1976), unambiguous evidence of this volcanic component was not forthcoming until pillow lavas, variously deformed and flattened, were recorded from Losomäki (Fig. 3; Park and Bowes 1981).

Geologists from the Exploration Department, Luikonlahti mine, had assigned a metavolcanic nature to the greenschists and banded amphibolites at Losomäki (T. Salaterä, pers. comm) but at that stage the pillow structures had not been identified. Subsequent mapping by the author and geologists from the Luikonlahti mine has revealed that, in addition to serpentinite, chrome-silicate skarn, dolomite, quartz rock and metalliferous black schist similar to that recognised throughout the Outokumpu region, rocks derived from a volcanic protolith form as much as $30 \%$ of the rock assemblage (referred to hereafter as the Outokumpu assemblage cf. Park 1983) in the Losomäki district (Fig. 1). Original volcanogenic features including pillows, vesicular lava, breccias and agglomerates have now been recognised in two localities, viz. Toivalanmäki WNW and Ylä Poskijärvi N of Losomäki. The features are preserved in low strain areas in greenschists and various amphib- olites interpreted as strongly deformed metavolcanic rocks. The overall outcrop pattern is consistent with tectonic units consisting of the various metavolcanic rocks being interdigitated with the chrome-silicate skarn, quartz rock, black schist and serpentinite of the Outokumpu assemblage and Kalevian mica schist (Figs. 1, $2)$. The present disposition is the result of thrusting during the $\mathrm{D}_{2}$ phase of deformation, during which the pattern of low strain enclaves among strongly deformed rocks was established. Strain during $\mathrm{D}_{2}$ was taken up largely in the vicinity of the thrust zones; during $D_{1}$ its expression appears to have been more homogenous throughout the lithologies now making up the tectonic stack. Even in low strain enclaves metamorphic reconstitution is virtually complete. At Toivalanmäki an early garnetamphibole assemblage is now largely retrogressed to chlorite greenschist, whereas at Ylä Poskijärvi the pillows are now pods of zoisiteamphibole with diopside, epidote and plagioclase in a chlorite-amphibole matrix.

Deformation brings about a drastic modification of morphology. At Ylä-Poskijärvi the transition from low to high strain is accompanied by flattening, folding and boudinage of pillows in their matrix, and though pillow and matrix remain as distinct lithons, the end product of such modification is a banded amphibolite (Park and Bowes 1981; cf. Ehlers 1978; Myers 1978; Gaál 1980). A similar modification of tuff-breccias and pillows to amphibole-chlorite schist can be demonstrated at Toivalanmäki.

Although only two low-strain enclaves have been discovered, the amphibole-chlorite greenschists and banded amphibolites in the area show certain characteristics of mineralogy and mineral and whole-rock chemistry that imply a volcanogenic derivation. These features, established around Losomäki, have been used as the bases for interpreting other greenschists and amphibolites in other outcrops of the Outokumpu assemblage as being of a volcanogenic parentage even though no original structural or tex- 


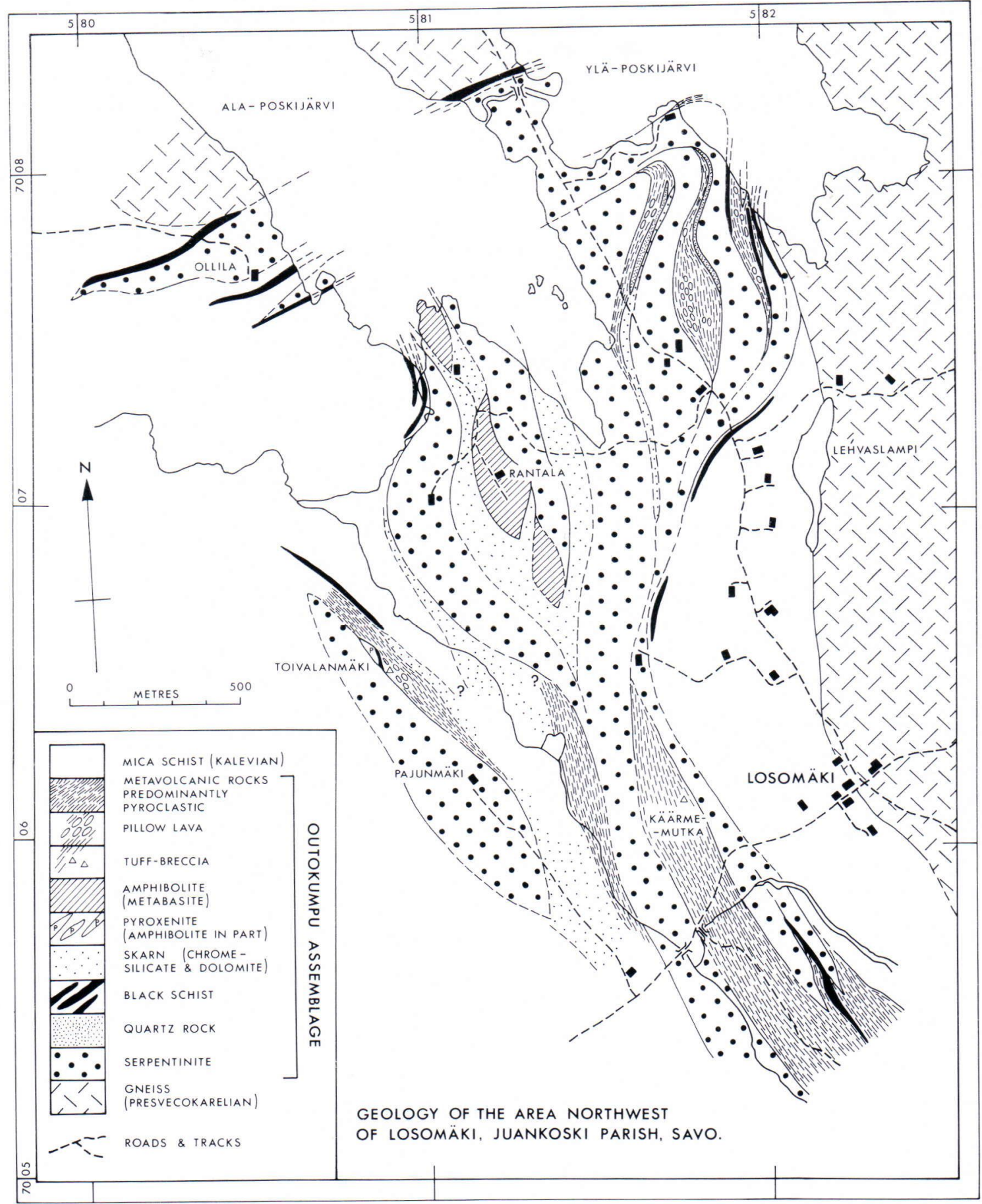

Fig. 1. Geology of the area NW of Losomäki, Juankoski parish, Savo; based on field maps augmented by drill data and interpretation of geophysical data provided by the Exploration Department, Luikonlahti mine (Myllykoski Oy). 


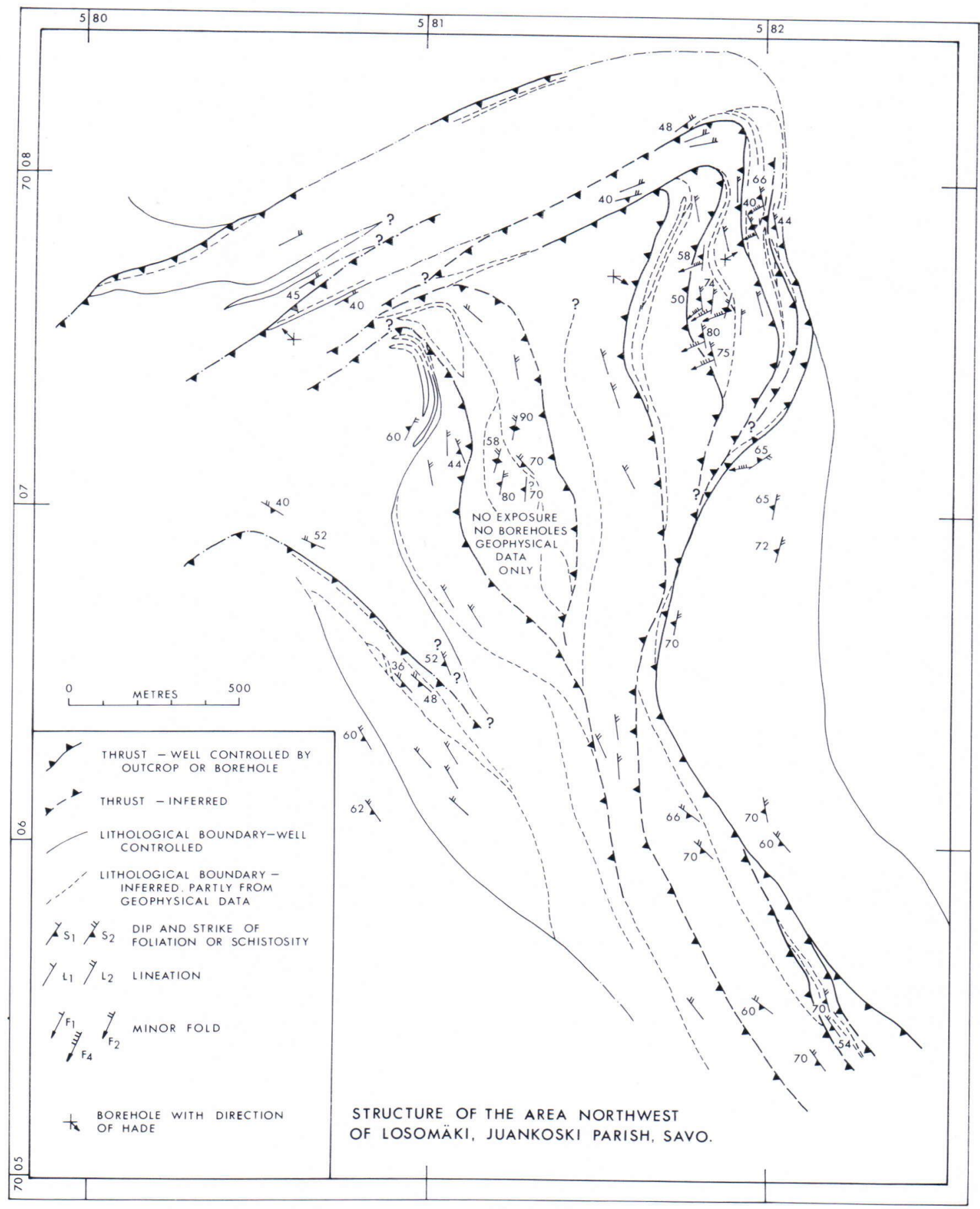

Fig. 2. Structure of the area NW of Losomäki; lithological boundaries as in Figure 1. 


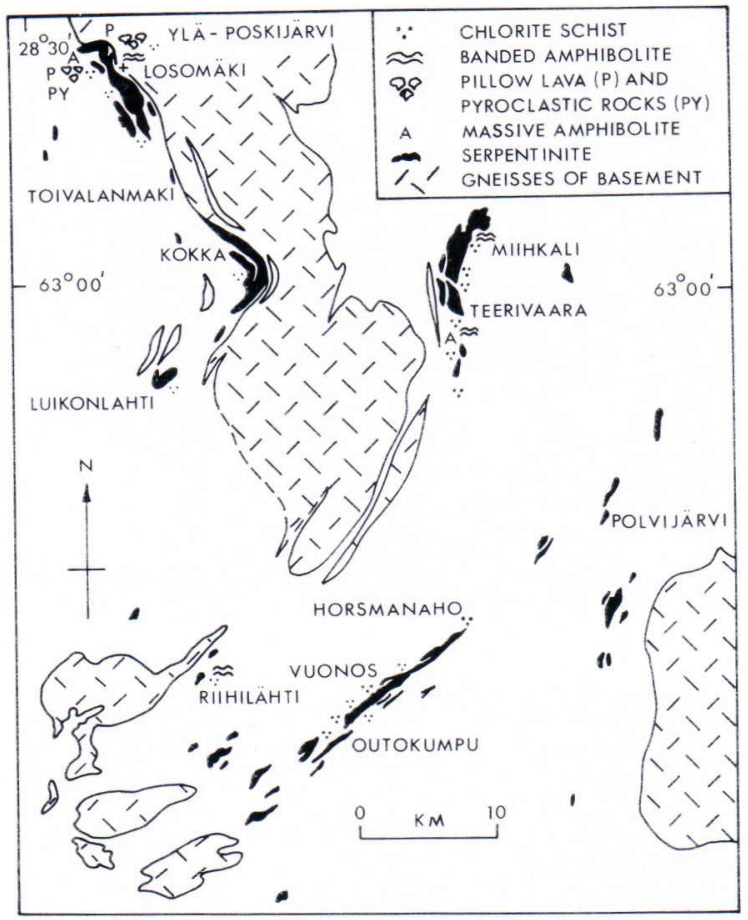

Fig. 3. Distribution of metavolcanic rock-types in the Outokumpu region.

tural features have been seen (Fig. 3). With the exception of the belt $\mathrm{S}$ of Polvijärvi, such rocks occur at most places where the Outokumpu assemblage has been recorded. However it is only in the Losomäki and Miihkali areas that they constitute a major fraction of the assemblage.

Most of the exposure of the low strain enclaves in which the original volcanogenic features have been recognised is either recently cleared or is in exploration trenches, but rocks similar to those interpreted as being their tectonised equivalents have been known for some time. They are recorded as chlorite, chloriteepidote or chlorite-amphibole »skarn» or just »skarn» on the maps of Huhma (1975), and are similarly recorded as "skarn" in the underground mine workings at Outokumpu (Fig. 4; $c f$. Koistinen 1981, fig. 11 a). They are epidoteor zoisite-bearing amphibole and/or chlorite schists that can be distinguished from other rocks of similar fabric and superficially similar mineralogy in the Outokumpu assemblage on the basis of mineral and whole-rock chemistry. In particular they are distinctly different from the epidote-zoisite-bearing chrome-silicate skarns and the chloritic phyllonites derived, by deformation and metamorphism, from serpentinite.

In terms of gross lithology, the Toivalanmäki and the Ylä-Poskijärvi rock associations form two distinct units. Even where deformed, they are sufficiently distinct to form mappable entities. Accordingly, for convenience of description, they are treated separately, but this separation has no petrogenetic significance.

Two other distinct lithologies occur in the Losomäki district whose relationships with the clearly identifiable volcanic rocks cannot be determined unequivocally from available evidence. (1) A pyroxenite body appears to form an integral part of the metavolcanic unit at Toivalanmäki. Its contact is partly obscured by alteration, but there appears to be a gradation
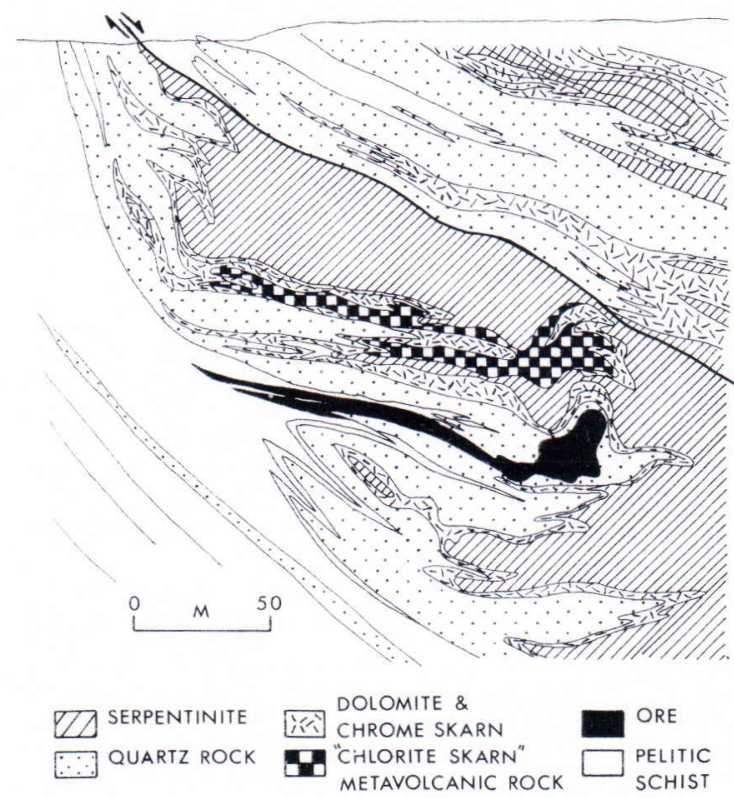

Fig. 4. „Chlorite skarn» interpreted as metavolcanic rock, Outokumpu; section of the Keretti mine after Koistinen (1981, fig. 11 a). 

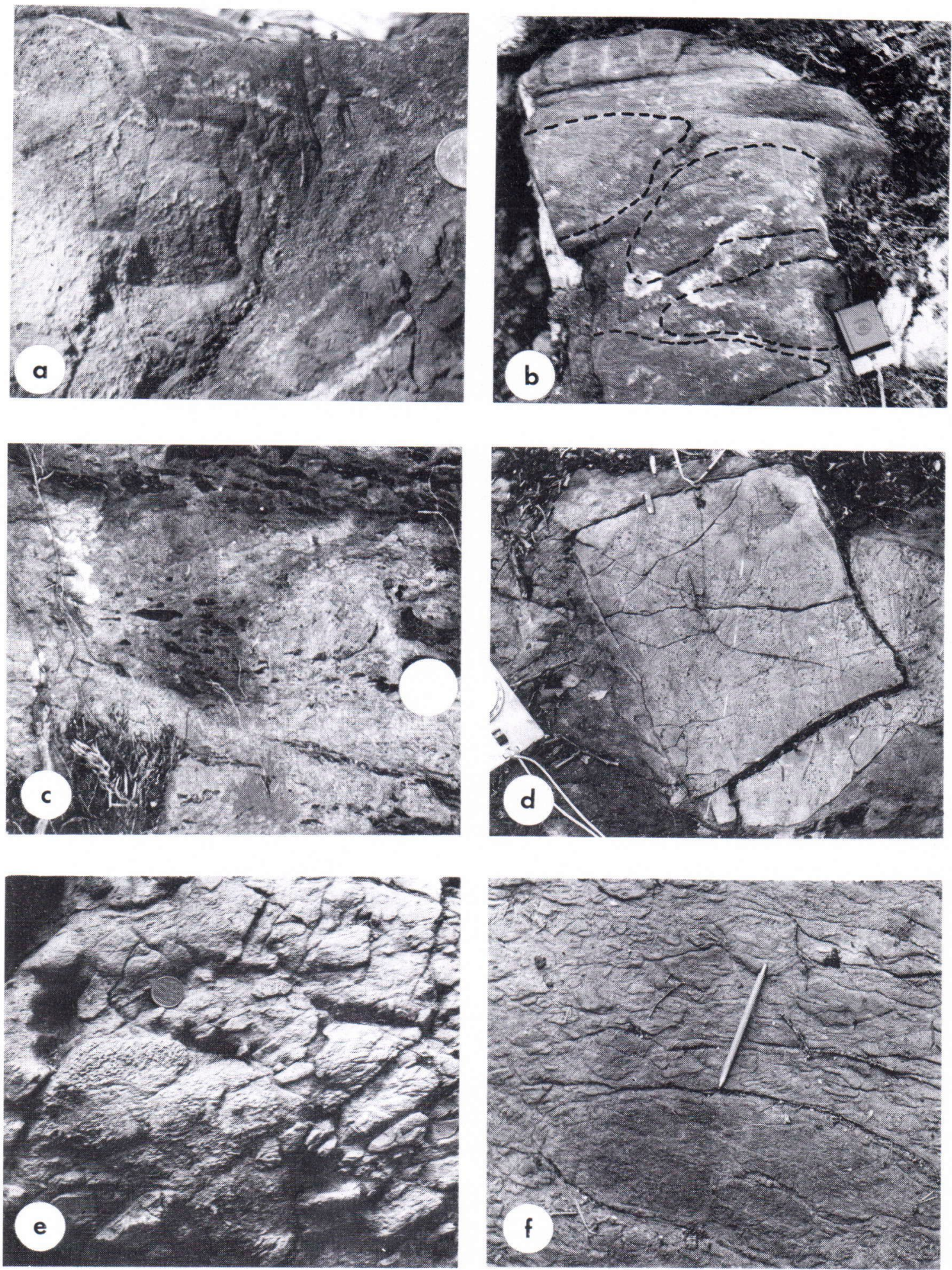

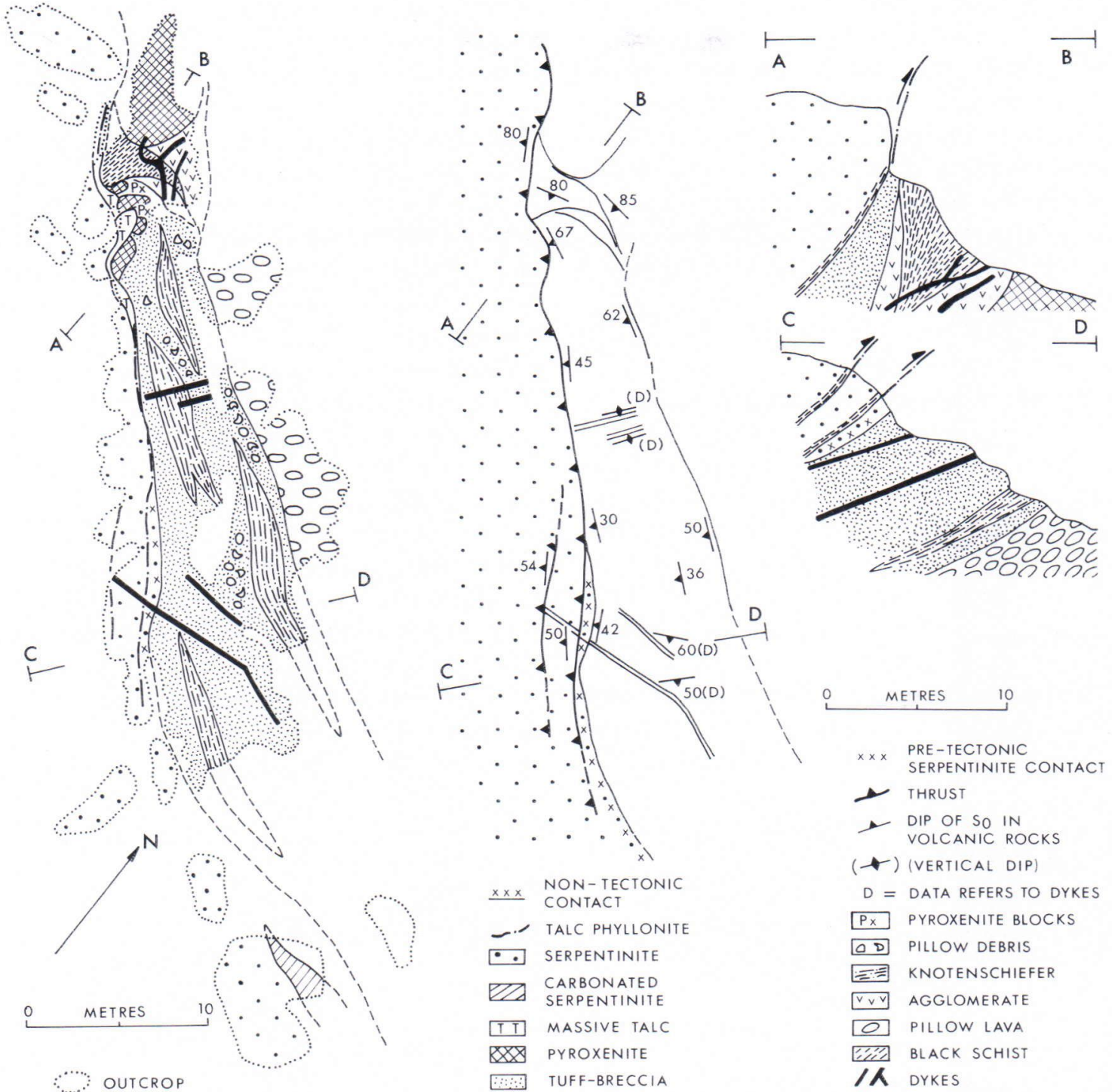

Fig. 6. Plane table map and cross-sections of the Toivalanmäki exposure, $1.5 \mathrm{~km}$ WNW of Losomäki (see Fig. 1). (a) Distribution of metavolcanic lithologies. (b) Structural elements in the metavolcanic lithologies. (c) Cross-sections A-B, C-D through the exposure.

Fig. 5. Original volcanogenic features (a) Margin of a pillow structure showing compositional banding picked out by garnet concentrations; Toivalanmäki, coin $=1.8 \mathrm{~cm}$. (b) Epidote-chlorite-emphibole rock with relict pillow structures; Toivalanmäki. (c) Weathered out vesicles on the surface of amphibole-epidote-chlorite rock, considered to be metamorphosed vesicular lava; Toivalanmäki, coin $=2.2 \mathrm{cms}$. (d) Angular block (basalt ?) in vesicular matrix (vesicular lava); this rock is considered to be agglomerate; Toivalanmäki. (e) Block of vesicular lava (now chlorite-epidote rock) in a matrix of metatuff (now a fine-grained greenschist); tuff breccia; Toivalanmäki, coin $=2.2 \mathrm{~cm}$. (f) Tuff-breccia with blocks of finegrained greenschist (metatuff) in similar matrix; Toivalanmäki, pencil $=15 \mathrm{~cm}$. 
into vesicular lava. Pyroxenite blocks occur in the tuff-breccia (Fig. 8 a, b). (2) A massive amphibolite occurs at two exposures between two farms called Rantala, S of Ylä-Poskijärvi (Fig. 1). Its eastern margin appears to be in tectonic contact with serpentinite and its western margin lies under swamp. Geophysical surveys suggest that the mass is fragmented and extends for several hundred metres under the swamp, $\mathrm{S}$ of Ala-Poskijärvi.

\section{Original volcanic features and lithologies}

The rocks are all strongly recrystallised and, apart from rare mineral relics, the identifiable volcanogenic features are essentially morphological.

\section{Toivalanmäki}

Deformation and tectonic fabric development is minimal and a number of original volcano- genic features remain (see Fig. 7). However the rocks are agglomerate with a gradational relationship to the vesicular lava that at least in part also forms its matrix.

Much of the outcrop consists of a patchy rock in which a fine-grained matrix contains distinct angular blocks. Some of these are mineralogically the same as the matrix but still have distinct boundaries; others are mineralogically the same as the rocks interpreted as pillow lavas, or vesicular lavas (Fig. 5 e, d). That the rock is a polymict breccia is apparent, but the presence of fragments of volcanic rock and the similarities between blocks and matrix suggest it is a tuff-breccia. Recognisable blocks include vesicular lava (Fig. 5 e), pillow material, including portions of the layered rims, and blocks of pyroxenite (Fig. 8 a, b). Some parts of the unit are without blocks, and are interpreted as tuff.

Pyroxenite, amphibolitised to varying degrees, occurs both as blocks within the tuff-breccia and as disconnected masses along the serpentinite contact (Figs $6 \mathrm{a}, 8 \mathrm{a}, \mathrm{b}$ ). In places, it dis-
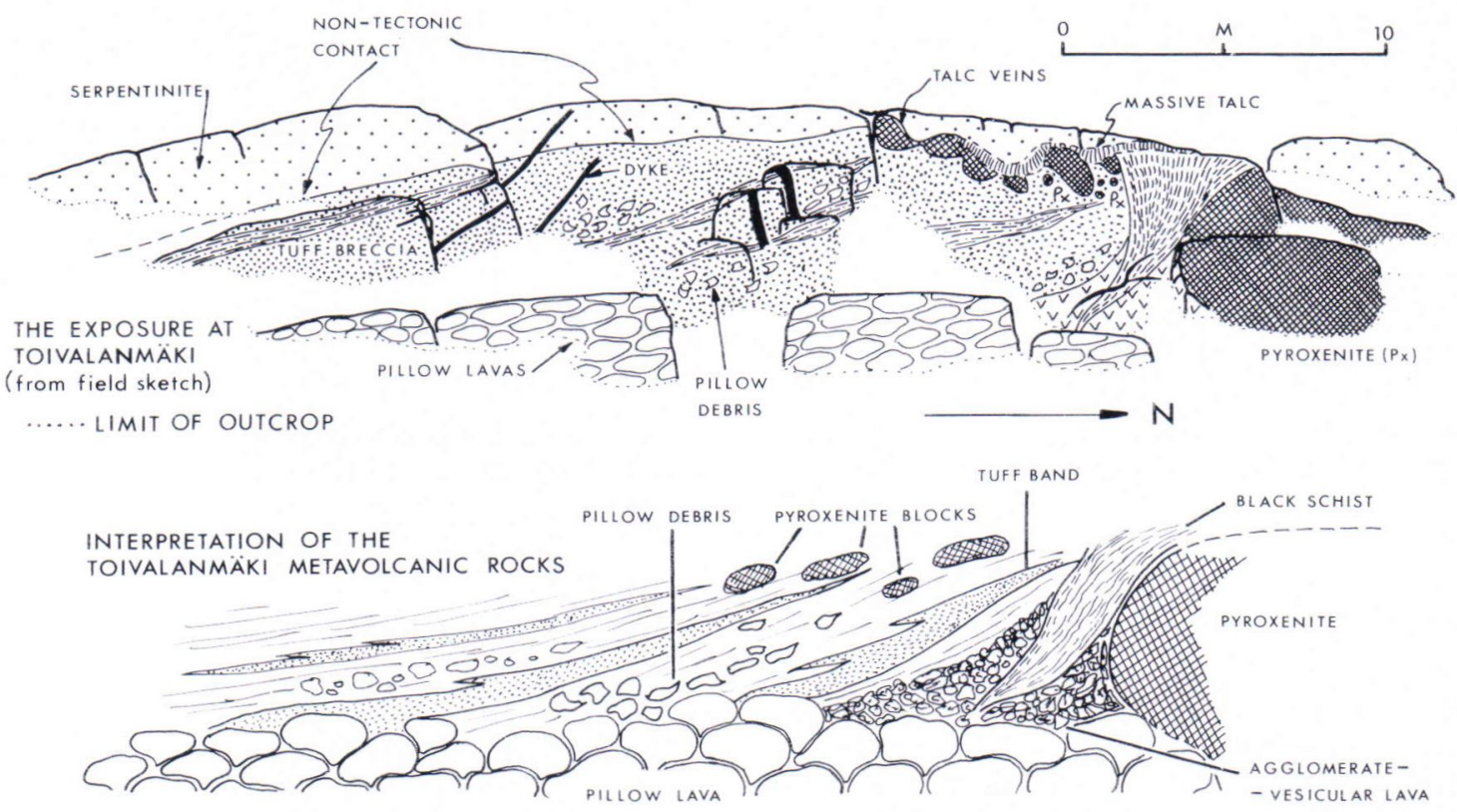

Fig. 7. Rock relationships shown on the low cliff exposure at Toivalanmäki, and a reconstruction of the original configuration; legend is the same as that used in Figure 6. 
plays an apparently gradational contact with vesicular lava although there is much chlorite and talc growth at the contact. It now consists mainly of secondary hornblende but there are relict patches of coarse-grained diopsidic clinopyroxene without any apparent zonation or exsolution phenomena. There are also much fractured grains of clinopyroxene. Carbon is an essential phase of veinlets along these fractures; granular or amorphous masses of carbon are also interstial to the hornblende. Ore minerals present include antimony-bearing niccolite, this being the only recorded arsenical phase in this study. The relationship of the pyroxenite to other volcanic features is illustrated in Figure 9 e.
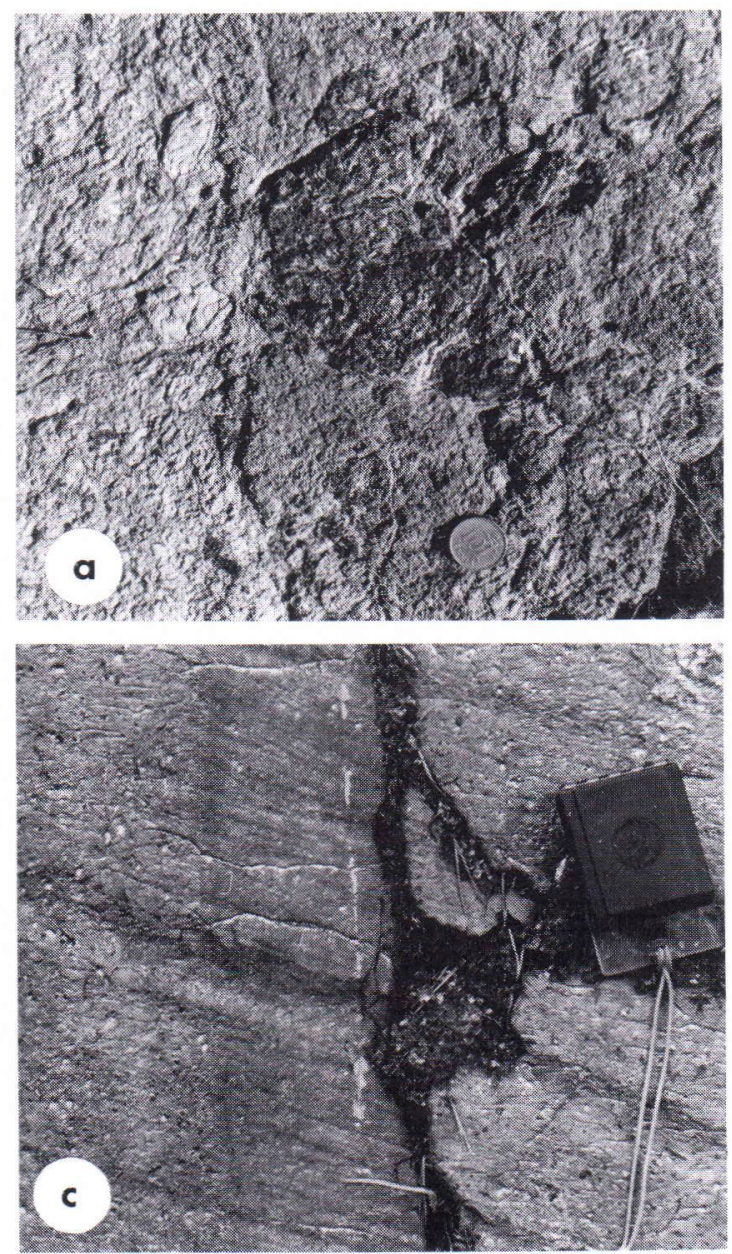

\section{Ylä-Poskijärvi}

Elongate masses composed of zoisite and amphibole with smaller proportions of epidote, diopside, andesine, chlorite and carbonate surrounded by finer-grained rims in a greenschist matrix have been interpreted as being pillows by Park and Bowes (1981). The matrix is interpreted as'tuff. Both the mineralogy and chemical composition of these pillows indicates that there has been substantial alteration (Table 1), although it is static growth of actinolitic amphibole and not a relict igneous texture which accounts for what Park and Bowes (1981) referred to as »ophitic texture». A mineralo-

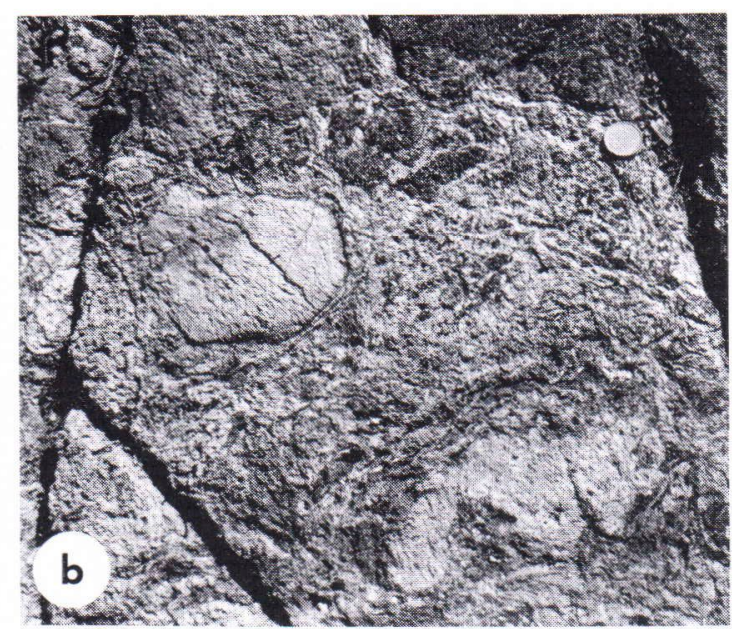

Fig. 8. (a) Pyroxenite blocks in tuff-breccia; Toivalanmäki, coin $=1.8 \mathrm{~cm}$. (b) Amphibolitised (dark) and steatised (white) pyroxenite blocks in tuff-breccia; Toivalanmäki, coin $=2.2 \mathrm{~cm}$. (c) Chloritised basic dyke in greenschist interpreted as metatuff; Toivalanmäki. 
gical peculiarity is the occasional presence of small grains of tawmawite (Cr-epidote) enclosing grains of zincian chrome-spinel.

\section{Rantala}

The medium-grained hornblende-plagioclasequartz-bearing amphibolite mass at Rantala shows no banding or compositional zoning but is pervasively foliated. Several mineral fabrics are present. Although classed as »skarn» on the 1 : 100,000 geological map of Huhma (1975), it has characteristics that would indicating that it was an orthoamphibolite. Whether it represents a sill or an extrusive basic flow cannot be determined from the available evidence.

\section{Mineral and whole-rock chemistry of undeformed volcanogenic products}

The lithological differences between rocks that retain recognisable volcanogenic features in the Ylä-Poskijärvi and the Toivalanmäki associ-

Table 1. Ylä-Poskijärvi association metavolcanic rocks.

\begin{tabular}{|c|c|c|c|c|c|c|c|c|}
\hline \multicolumn{9}{|c|}{ Chemical analyses } \\
\hline & 1 & 2 & 3 & 4 & 5 & 6 & 7 & 8 \\
\hline $\mathrm{SiO}_{2}$ & 44.69 & 44.36 & 42.54 & 42.40 & 42.06 & 30.05 & 46.47 & 45.04 \\
\hline $\mathrm{TiO}_{2}$ & 0.71 & 0.67 & 0.57 & 0.61 & 0.65 & 0.27 & 0.31 & 0.62 \\
\hline $\mathrm{Al}_{2} \mathrm{O}_{3}$ & 21.56 & 20.56 & 26.21 & 24.25 & 24.22 & 18.23 & 14.43 & 13.27 \\
\hline $\mathrm{FeOt}$ & 6.24 & 6.38 & 3.39 & 4.38 & 4.55 & 11.28 & 5.95 & 8.46 \\
\hline $\mathrm{MnO}$ & 0.10 & 0.07 & 0.07 & 0.10 & 0.09 & 0.04 & 0.08 & 0.13 \\
\hline $\mathrm{MgO}$ & 7.64 & 6.55 & 2.88 & 4.24 & 4.00 & 28.86 & 9.13 & 10.40 \\
\hline $\mathrm{CaO}$ & 15.26 & 16.41 & 20.86 & 20.85 & 20.59 & 0.17 & 12.73 & 13.04 \\
\hline $\mathrm{Na}_{2} \mathrm{O}$ & 0.74 & 0.68 & 0.03 & 0.35 & 1.03 & 0.63 & 3.98 & 1.50 \\
\hline $\mathrm{K}_{2} \mathrm{O}$ & 0.33 & 0.36 & 0.08 & 0.11 & 0.31 & 0.13 & 0.72 & 0.20 \\
\hline $\mathrm{P}_{2} \mathrm{O}_{5}$ & 0.04 & 0.04 & 0.10 & 0.06 & 0.13 & 0.05 & 0.08 & 0.04 \\
\hline Total & 97.31 & 96.08 & 96.73 & 97.35 & 97.63 & 89.11 & 93.88 & 92.70 \\
\hline \multicolumn{9}{|c|}{ Trace elements (p.p.m.) } \\
\hline $\mathrm{Zr}$ & 64 & 58 & 55 & 44 & 52 & 24 & 22 & 53 \\
\hline $\mathrm{Y}$ & 30 & 23 & 25 & 23 & 28 & 2 & 12 & 17 \\
\hline $\mathrm{Sr}$ & 322 & 351 & 421 & 393 & 447 & 12 & 224 & 190 \\
\hline U & 1 & 2 & 3 & 2 & 2 & 1 & 3 & 1 \\
\hline $\mathrm{Rb}$ & 5 & 7 & - & - & 4 & - & 9 & 2 \\
\hline Th & 3 & 3 & 2 & 3 & 3 & 3 & 4 & 1 \\
\hline $\mathrm{Pb}$ & 15 & 17 & 45 & 37 & 53 & 3 & 6 & 17 \\
\hline $\mathrm{Ga}$ & 16 & 13 & 23 & 22 & 22 & 11 & 10 & 13 \\
\hline $\mathrm{Zn}$ & 93 & 88 & 35 & 57 & 71 & 206 & 104 & 199 \\
\hline $\mathrm{Cu}$ & 103 & 74 & 19 & 26 & 56 & 4 & 83 & 41 \\
\hline $\mathrm{Ni}$ & 310 & 238 & 210 & 276 & 276 & 146 & 4922 & 192 \\
\hline Co & 69 & 51 & 48 & 58 & 64 & 59 & 79 & 58 \\
\hline $\mathrm{Cr}$ & 1257 & 1027 & 855 & 970 & 1021 & 191 & 1180 & 1014 \\
\hline $\mathrm{Ce}$ & 21 & 19 & 13 & 9 & 19 & 10 & 24 & 19 \\
\hline $\mathrm{Ba}$ & 87 & 128 & - & 12 & 11 & - & 67 & - \\
\hline $\mathrm{La}$ & - & - & 4 & 1 & 3 & - & - & 3 \\
\hline
\end{tabular}

\section{Explanation of Table 1}

1-5 Pillows (see Park and Bowes 1981, fig. 2)

6-8 Tuff matrix of pillows (see Park and Bowes 1981, fig. 2) $\mathrm{FeOt}-$ total $\mathrm{Fe}$ as $\mathrm{FeO}$.

All analyses by XRF, Philips Pw 1450, University of Glasgow. 
ations are reflected in their respective chemical characteristics (Tables 1, 2). The present mineral assemblage of neither association corresponds directly to any volcanogenic analogue suggesting that their parageneses involve alteration and movement of material. This is to be expected in the shallow water marine environment of formation indicated by the rock association and their morphological features (see section 4), where spilitisation of pillows and saturation of glass-rich tuffs by seawater is to be expected. Accordingly it is necessary to determine whether the present differences between the Ylä-Poskijärvi and Toivalanmäki associations reflect different modes of alteration of the same protolith or original differences is composition in rocks that appear to have some general affinities with basaltic komatiites.

Table 2. Toivalanmäki association metavolcanic rocks.

\begin{tabular}{|c|c|c|c|c|c|c|c|c|}
\hline \multicolumn{9}{|c|}{ Chemical analyses } \\
\hline & 1 & 2 & 3 & 4 & 5 & 6 & 7 & 8 \\
\hline $\mathrm{SiO}_{2}$ & 31.31 & 39.14 & 37.92 & 27.89 & 53.84 & 50.11 & 39.04 & 28.80 \\
\hline $\mathrm{TiO}_{2}$ & 0.47 & 0.38 & 0.36 & 0.43 & 0.66 & 0.06 & 0.36 & 0.42 \\
\hline $\mathrm{Al}_{2} \mathrm{O}_{3}$ & 16.39 & 12.72 & 12.94 & 19.19 & 12.63 & 1.59 & 11.96 & 18.63 \\
\hline $\mathrm{FeOt}$ & 26.64 & 22.50 & 22.80 & 27.78 & 11.86 & 13.63 & 20.00 & 27.79 \\
\hline $\mathrm{MnO}$ & 0.22 & 0.48 & 0.58 & 0.30 & 0.15 & 0.19 & 0.46 & 0.34 \\
\hline $\mathrm{MgO}$ & 16.70 & 13.92 & 13.91 & 16.09 & 6.05 & 15.70 & 16.90 & 15.04 \\
\hline $\mathrm{CaO}$ & 2.91 & 5.62 & 5.42 & 1.30 & 10.41 & 11.11 & 5.35 & 1.42 \\
\hline $\mathrm{Na}_{2} \mathrm{O}$ & 0.40 & 0.92 & 0.40 & 0.05 & 1.66 & 0.30 & n.d. & 0.30 \\
\hline $\mathrm{K}_{2} \mathrm{O}$ & 0.15 & 0.18 & 0.15 & 0.09 & 0.21 & 0.12 & 0.10 & 0.09 \\
\hline $\mathrm{P}_{2} \mathrm{O}_{5}$ & 0.06 & 0.06 & 0.04 & 0.03 & 0.05 & 0.01 & 0.03 & 0.03 \\
\hline Total & 95.25 & 95.92 & 94.52 & 93.15 & 97.52 & 92.82 & 94.20 & 92.86 \\
\hline
\end{tabular}

Trace elements (p.p.m.)

\begin{tabular}{|c|c|c|c|c|c|c|c|c|}
\hline $\mathrm{Zr}$ & 28 & 28 & 25 & 37 & 40 & 16 & 28 & 34 \\
\hline Y & 15 & 21 & 29 & 18 & 19 & 10 & 30 & 15 \\
\hline $\mathrm{Sr}$ & 23 & 25 & 25 & 13 & 212 & 18 & 20 & 12 \\
\hline $\mathrm{U}$ & - & 3 & 2 & 1 & 3 & 3 & 1 & - \\
\hline $\mathrm{Rb}$ & - & 2 & 5 & 1 & 5 & - & - & - \\
\hline Th & 2 & 2 & - & 2 & 1 & 2 & 1 & 2 \\
\hline $\mathrm{Pb}$ & 2 & 4 & 3 & - & 5 & 7 & 2 & 2 \\
\hline $\mathrm{Ga}$ & 15 & 12 & 10 & 15 & 13 & 1 & 8 & 13 \\
\hline $\mathrm{Zn}$ & 174 & 244 & 245 & 209 & 231 & 120 & 279 & 209 \\
\hline $\mathrm{Cu}$ & 53 & 11 & 8 & 11 & 5 & 152 & 8 & 14 \\
\hline $\mathrm{Ni}$ & 518 & 574 & 557 & 394 & 239 & 4671 & 683 & 384 \\
\hline $\mathrm{Co}$ & 137 & 143 & 142 & 228 & 63 & 274 & 122 & 224 \\
\hline $\mathrm{Cr}$ & 1160 & 886 & 851 & 1311 & 889 & 3687 & 1080 & 1240 \\
\hline $\mathrm{Ce}$ & 62 & 40 & 42 & 63 & 21 & 35 & 36 & 59 \\
\hline $\mathrm{Ba}$ & - & - & - & - & 24 & - & - & - \\
\hline $\mathrm{La}$ & - & - & - & - & 4 & 1 & - & - \\
\hline
\end{tabular}

\section{Explanation of Table 2}

1-4 Pillow lava blocks from tuff breccia

Pillow (in situ)

Vesicular lava

$7-8$ Tuff breccia (small clasts and matrix)

FeOt Total Fe as FeO 


\section{Ylä-Poskijärvi association}

In the pillows the plagioclase and possibly even diopside may be relict, but whether they relate to the original assemblage is debatable. The plagioclase is very altered; this precluded reliable analysis by microprobe but optical methods indicate andesine $\left(c . \mathrm{An}_{40}\right)$. The diopside is very pure with low $\mathrm{Fe}($ c. $1 \%)$ and $\mathrm{Al}($ c. $2 \%)$ and with $\mathrm{Ni}$ and $\mathrm{Cr}$ below detection limits. The coarse static growth of amphibole is an actinolitic hornblende - magnesio-hornblende (cf. Leake 1978). It is aluminous ( $\mathrm{Al}^{\mathrm{IV}} / \mathrm{Si} \leqslant 0.01$ ); trace elements include $\mathrm{Ti}$ and $\mathrm{Cr}$ in small amounts but neither $\mathrm{Ni}$ nor $\mathrm{Co}$ has been detected. Epidote and zoisite approach ideal compositions with Mn being the only important trace element component. Cr levels are generally very low, although Cr-epidote (tawmawite) with inclusions of $\mathrm{Zn}-\mathrm{Cr}$ spinel is a rare accessory. Ferrichromite with very low $\mathrm{Al}$ is widespread but in accessory proportions. Pyrrhotite with minor pyrite and chalcopyrite occur; these have low $\mathrm{Ni}$ and Cr contents ( $<500$ p.p.m.).

The high $\mathrm{Al}_{2} \mathrm{O}_{3}(>20 \%)$ and $\mathrm{CaO}(>$ $15 \%$ ) reflect the zoisite and epidote in the pale coloured pillows and these proportions in relation to other major oxides are not comparable with any volcanic analogue. However there are many chemical features that distinguish the pillows from previously recorded lithologies of the Outokumpu assemblage, viz the considerably increased amounts of $\mathrm{Ti}, \mathrm{Sr}, \mathrm{Zr}, \mathrm{Y}$ and alkalies and the considerably decreased amounts of $\mathrm{Cr}$ and $\mathrm{Ni}$.

The greenschist matrix of the pillows consists of actinolitic hornblende of magnesio-hornblende that contains no detectable $\mathrm{Ni}$ or $\mathrm{Co}$ and $\mathrm{Mg}$ chlorite that may carry some $\mathrm{Cr}$ (c. 500 p.p.m.). The $\mathrm{Cr}$ proportions in both epidote and amphibole are low, but $\mathrm{Ti}$ is consistently present as a trace element in the silicates. Ore minerals are highly variable in both type and modal proportions, with either oxide (a Ti-magnetite or haematite) or sulphides (rarely both) - pyrite, chalcopyrite and pyrrhotite, some of the last mentioned being $\mathrm{Ni}$ - or Co-bearing. The $\mathrm{Al}_{2} \mathrm{O}_{3}$ in the matrix is generally only about half of that in the pillows whereas $\mathrm{MgO} / \mathrm{FeOtot}$ (see Tables $1,2,3)$ is $1.5-2.0$ compared with $0.85-1.5$ in the pillows. $\mathrm{Zr}$ and $\mathrm{Y}$, like $\mathrm{Sr}$, cover the same lower range, whereas $\mathrm{Ce}$ and $\mathrm{Co}$ are both present in higher levels.

\section{Discrimination using geochemistry}

The identification of these rocks as being derived from a volcanic protolith must ultimately depend on morphological criteria. Although mineral relics have compositions not inconsistent with a volcanic or igneous origin, diagnostic characteristics do not permit positive identification. Neither can whole-rock chemistry be used as not only do all the lithologies have compositions directly related to the observed secondary mineralogy, but also an irreducable degree of alteration from protolith composition is common in them all. However, a number of petrographic and compositional criteria can be given that distinguish these rocks from superficially similar skarn and schistose rocks in the Outokumpu assemblage. The criteria can be used to recognise the extent of the volcanic component in the Outokumpu assemblage.

1. Plagioclase, when it occurs, is diagnostic of volcanogenic rocks; it does not occur in any chrome silicate- or zoisite-bearing skarns.

2. Clinopyroxene and amphibole in the volcanogenic rocks have lower $\mathrm{Cr}, \mathrm{Ni}$ and $\mathrm{Co}(<$ 500 p.p.m., 100 p.p.m. and 100 p.p.m., respectively), and have higher $\mathrm{Ti}$ ( $>500$ p.p.m.) than pyroxene and amphibole in other skarns. The amphibole is usually actinolitic hornblende or magnesio-hornblende rather than the anthophyllite-cummingtonitetremolite found in chlorite phyllonite derived from serpentinite.

3. Epidote group minerals in the volcanogenic rocks are generally low in $\mathrm{Cr}, \mathrm{Ni}$ and $\mathrm{Ca}(<$ 
Table 3. Amphibolites.

\begin{tabular}{|c|c|c|c|c|c|c|c|}
\hline & 1 & 2 & 3 & 4 & 5 & 6 & 7 \\
\hline \multicolumn{8}{|c|}{ Chemical analyses } \\
\hline $\mathrm{SiO}_{2}$ & 47.05 & 46.40 & 43.35 & 43.11 & 51.23 & 55.02 & 51.26 \\
\hline $\mathrm{TiO}_{2}$ & 0.45 & 0.45 & 0.45 & 0.44 & 0.36 & 0.66 & 0.58 \\
\hline $\mathrm{Al}_{2} \mathrm{O}_{3}$ & 15.60 & 17.04 & 16.43 & 17.30 & 17.11 & 12.72 & 14.63 \\
\hline $\mathrm{FeOt}$ & 9.12 & 7.50 & 9.40 & 5.57 & 3.93 & 11.05 & 10.26 \\
\hline $\mathrm{MnO}$ & 0.13 & 0.13 & 0.18 & 0.10 & 0.06 & 0.17 & 0.14 \\
\hline $\mathrm{MgO}$ & 10.27 & 9.29 & 12.36 & 8.00 & 8.29 & 6.96 & 7.65 \\
\hline $\mathrm{CaO}$ & 13.26 & 16.44 & 14.54 & 20.41 & 10.26 & 9.24 & 11.21 \\
\hline $\mathrm{Na}_{2} \mathrm{O}$ & 0.72 & 0.41 & 0.19 & 0.23 & 4.13 & 2.22 & 2.10 \\
\hline $\mathrm{K}_{2} \mathrm{O}$ & 0.69 & 0.34 & 0.17 & 0.13 & 0.46 & 0.20 & 0.37 \\
\hline $\mathrm{P}_{2} \mathrm{O}_{5}$ & 0.04 & 0.03 & 0.03 & 0.03 & 0.04 & 0.06 & 0.06 \\
\hline Total & 97.33 & 98.03 & 97.10 & 95.32 & 95.87 & 98.30 & 98.26 \\
\hline \multicolumn{8}{|c|}{ Trace elements (p.p.m.) } \\
\hline $\mathrm{Zr}$ & 39 & 35 & 35 & 32 & 26 & 51 & 40 \\
\hline Y & 19 & 18 & 16 & 20 & 14 & 25 & 22 \\
\hline $\mathrm{Sr}$ & 185 & 168 & 93 & 225 & 195 & 72 & 74 \\
\hline $\mathrm{U}$ & 3 & 2 & 1 & 1 & 1 & 1 & - \\
\hline $\mathrm{Rb}$ & 13 & - & - & - & 4 & - & 1 \\
\hline Th & 1 & 1 & 2 & 2 & 1 & 2 & 2 \\
\hline $\mathrm{Pb}$ & 6 & 2 & 3 & 5 & 2 & 3 & - \\
\hline $\mathrm{Ca}$ & 10 & 10 & 11 & 12 & 10 & 11 & 14 \\
\hline $\mathrm{Zn}$ & 83 & 67 & 81 & 70 & 80 & 60 & 57 \\
\hline $\mathrm{Cu}$ & 5 & 23 & 10 & 72 & 41 & 12 & 129 \\
\hline $\mathrm{Ni}$ & 304 & 328 & 129 & 206 & 281 & 65 & 99 \\
\hline $\mathrm{Co}$ & 53 & 56 & 39 & 35 & 30 & 44 & 43 \\
\hline $\mathrm{Cr}$ & 872 & 906 & 852 & 832 & 1291 & 35 & 177 \\
\hline $\mathrm{Ce}$ & 17 & 16 & 17 & 15 & 9 & 15 & 22 \\
\hline $\mathrm{Ba}$ & 399 & 65 & 41 & - & 39 & 28 & 7 \\
\hline $\mathrm{La}$ & - & - & - & - & - & - & - \\
\hline
\end{tabular}

\section{Explanation of Table 3}

1-5 Banded amphibolite; highly deformed pillows and tuff matrix of Ylä-Poskijärvi association (see Park and Bowes 1981). 6-7 Massive amphibolite, Rantala.

$\mathrm{FeOt}$ - total $\mathrm{Fe}$ as $\mathrm{FeO}$

800 p.p.m., 100 p.p.m. and 100 p.p.m., respectively), whereas in the skarns they have Cr compositions through the whole range up to tawmawite (7-8 \% $\mathrm{Cr}_{2} \mathrm{O}_{3}$; Eskola 1933) in true skarns. Tawmawite itself occurs in both.

4. Spinel in metavolcanic rocks is generally magnetite or low-Al chromite; in the nonvolcanogenic chlorite phyllonite it is either high-Al $(>2 \%)$ chromite or ferrichromite; the presence of ilmenite or Ti-iron oxides is not diagnostic.

5. Garnet in metavolcanic rocks contains a negligible uvarovite fraction $(<1 \%)$, whereas in all skarns it is the major molecular component (always $>60 \%$, usually $>90 \%$ ).

6. In bulk chemistry metavolcanic rocks have low $\mathrm{Cr}_{2} \mathrm{O}_{3} / \mathrm{CaO}(<1000)$ and higher $\mathrm{Ca} / \mathrm{C}$ $(>6$ ), the latter reflecting the independence of $\mathrm{CaO}$ content of modal carbonate. $\mathrm{TiO}_{2}$ is high for an Outokumpu assemblage lithology ( $>1000$ p.p.m.), as are $\mathrm{Al}_{2} \mathrm{O}_{3}$ ( $>2$ 
wt $\%$ ) and $\mathrm{Sr}$ (>10 p.p.m., usually $>100$ p.p.m.).

\section{Magmatic affinities}

The field subdivision into Toivalanmäki and Ylä-Poskijärvi associations is not reflected in the trace element ratios ( $\mathrm{Ti} / \mathrm{Y}, \mathrm{Ti} / \mathrm{Zr}$ and $\mathrm{Zr} / \mathrm{Y}$ ) indicating that the whole suite of rociss is cognate (Fig. 12 b, c, d). Even the Rantala amphibolite, which is so different in field features, shares certain characteristics with the above associations.

The original composition of the suite appears to have been basic, or at least mafic, or possibly ultramafic with the only original relics being clinopyroxene and pseudomorphs after olivine. This is supported by the highly magnesian nature of the least radically altered lavas. The most magnesium-rich material is that interpreted as metatuff and tuff-breccia. However this compositional characteristic cannot be taken as an original feature because of the known absorptive behaviour of basic glass in contact with magnesium-bearing sea water ( $c f$. Beswick 1982; Seyfried and Mottl 1982). Significantly the only occurrence of possibly relict plagioclase is in the most radically altered pillow lavas at Ylä-Poskijärvi ( $c f$. McGeehan and McLean 1980).

The presence of pseudomorphs of chrysotile after possible skeletal (? spinifex) original olivine in pillow cores would be consistent with the concept that at least some of the pillow lavas have komatiitic affinites ( $c f$. Arndt and Brooks 1980; Arndt and Nesbitt 1982). A similar conclusion may be drawn from the association of pyroxenite with vesicular lava ( $c f$. Arndt et al. 1979).

The most radical alteration seen in the pillow lavas of Ylä-Poskijärvi is reflected in the metamorphic mineral assemblage and the earliest relics (diopside and plagioclase). This indicates that the present major oxide composition is a pre-metamorphic feature.

\section{Field relations of undeformed volcanogenic products}

\section{Toivalanmäki}

(i) Pillow and vesicular lavas with the tuffbreccia. The tuff-breccia presently overlies pillow lavas and vesicular lava (Fig. 7) that, in turn, appears to overlie pillow lavas, though a direct relationship cannot be demonstrated. The way up cannot be demonstrated directly, but the presence of mineralogically identical and compositionally similar pillow and vesicular lava clasts in the tuff-breccia would imply that the present configuration is the original one. The actual contact between tuff-breccia and vesicular lava is quite sharp, and vesicular lava debris occurs in the tuff-breccia within centimetres of the contact. The contact between tuffbreccia and pillow lava is more gradational in that the pillow lavas gradually include more tuff matrix, and over quite a short distance $(<1 \mathrm{~m})$ whole pillows are replaced by pillow fragments and then by more mixed debris including vesicular lava and tuff clasts.

(ii) Pyroxenite, vesicular lava and agglomerate. Contacts between all three are gradational, the sequence being agglomerate with vesicular lava matrix - vesicular lava-pyroxenite working inward from the sharp contact with tuff-breccia. The conclusions regarding the way up are also supported if the agglomerate is considered to be the top of a lava unit that may have a pyroxenite core.

(iii) Pyroxenite - tuff-breccia. Although no direct contact has been observed, but clasts of pyroxenite occur in the tuff-breccia (Fig. 8 a, b) at the present top of the tuff-breccia unit. This is consistent with the fact that part of the tuff-breccia was formed later than, and contains debris from the pyroxenite - vesicular lava - agglomerate unit.

(iv) Metavolcanic rocks - serpentinite. For nearly $50 \%$ of the length of the exposure (Fig. 6) the serpentinite has an undulating, nontectonised margin against non-deformed tuff- 
breccia (Fig. 6). A small thrust ( $\mathrm{D}_{2}$ structure) runs through the serpentinite about two metres above this contact in the southern part of the exposure, and forms the contact at the northern end. Thus the serpentinite contact with the pyroxenite is both sheared and steatitised (Fig. 7).

(v) Dykes. A number of these, now completely chloritised (Fig. $8 \mathrm{c}$ ) cut all the lithologies seen, including serpentinite. They are not disrupted as they cross the tuff-serpentinite contact, but they do not appear to cut the thrusts (Fig. 6).

\section{Ylä-Poskijärvi}

The ratio of pale pillow to tuff matrix varies from individual exposures without pillows to sites where pillows predominate. Some matrix is always present but there does not appear to be much regularity in the arrangement within the tectonic unit. No evidence of the way up has been observed.

\section{Sequence of events}

The following is the sequence deduced from field observations at both Toivalanmäki and Ylä-Poskijärvi.

1. Eruption of pillows with some contemporaneous tuff.

2. Deposition of tuff with pillow debris.

3. Eruption of vesicular lavas with debris shed into the tuff-breccia.

4. Emplacement of pyroxenite in the core of vesicular lava unit.

5. Shedding of pyroxenite debris into the tuffbreccia.

6. Non-tectonic emplacement of ultramafic protolith to the serpentinite.

7. Dyke emplacement.

\section{Environment of volcanism}

The original morphological features of the metavolcanic rocks in the Losomäki area give a direct indication of the environment of formation of one member of the Outokumpu assemblage. The interpretation of the environment of formation of the dolomites and carbonaceous pelites is bedevilled by wider controversies regarding the redox state of the early Proterozoic atmosphere and hydrosphere; the presence of pillow lavas reflects eruption into water, regardless of the subtleties of its chemistry. The nature of this aqueous environment is reflected directly in the morphology of the pillows, and particularly in the nature and volume of the pyroclastic component and its relationships to consolidated lavas (cf. Hyde 1980; Bluck 1982).

The presence of pillows is not only a unique indication of the subaqueous eruptive environment but also an indication of water depth because the amount of explosive phreatic activity on a lava flow front advancing in water is depth dependent (i.e. hydrostatic pressure must be less than steam gas pressure). The mixing of pillows in a matrix of tuff produced by phreatic decrepitation of the quenched pillow skin is probably a unique indication of shallow water, e.g. a subtidal, littoral, lacustrine or sub-glacial environment. In such an environment the flow front generates an autoclastic breccia of hyalotuff, pillow fragments and complete, budded-off pillows ( $c f$. Moore 1975; Bluck 1982). The resultant deposit is very poorly sorted and thoroughly brecciated; it is also co-magmatic with the lava.

The amount and nature of the tuff fraction and its relationship to the lavas is evidence of the reworking by sedimentary processes of deposits formed in the manner outlined above. Such a reworked deposit would become progressively more sorted, and its component clasts progressively rounded and reduced. A compositional sorting of clasts should also be achieved by the selective disintegration of glassy material and the more vesiculated lava (Bluck 1982). However, even if a tuff-lava mix is not produced in this way, the presence of a large pyroclastic fraction would indicate a source area for 
air-fall tephra. This would be achieved either by air-fall direct from an eruptive ash plume into the water body, or by fluvial redeposition. Whichever interpretation is invoked for deposition - eruption, such mixed rocks either formed a part of, or were formed in the vicinity of a shallow-water or sub-aerial volcanic edifice.

In the Losomäki rocks, recrystallisation, even in the low strain enclaves, is such that neither fine details of the tuff (e.g. glass shards) nor depositional fabrics (e.g. bedding) survive. What is seen is an intimate mix of pillows and tuff matrix (Ylä-Poskijärvi association) or a gradation from pillow pile, through a pillowtuff unit, into a poorly sorted tuff-breccia with angular clasts of all types, juxtaposed with massive vesicular lava and agglomerate (Toivalanmäki association). The tuff-breccia at Toivalanmäki appears to consist entirely of debris from the associated lavas, in a tuff matrix. With the exception of the agglomerate-vesicular lava pyroxenite mass, tuff is an important, or even the main component of the preserved volcanic assemblage. Even when the deformed metavolcanic rocks are taken into account (next section), tuff probably originally formed over $50 \%$ of the entire volcanic assemblage.

From the above considerations concerning the observed features, the Losomäki volcanic edifice is interpreted as representing a pillowtuff mound(s) that erupted onto the sea-floor in relatively shallow water. A pillow lava complex is envisaged as having erupted from fissures on the sea-floor, with the flow-front generating a hyalotuff-breccia (essentially flow-front autoclastic talus produced by phreatic decrepitation and including pillows budded and separated from the feeding lava-tubes, Moore 1975) and fragmented pillows. Repeated emissions of lava would eventually result in an interdigitated pillow-tuff mound consisting of pure pillow, tuffsupported pillow, tuff-breccia and pure tuff. The positions of the Ylä-Poskijärvi and Toivalanmäki association in such an edifice are illustrated in Figures $9 \mathrm{a}$ and $\mathrm{b}$.
The depth of the eruption represented by activity of this nature may vary considerably, as the temperature of the erupted lava affects the simple hydrostatic pressure-steam gas pressure relationship. Basaltic activity of this kind with, an eruption between $1100^{\circ}$ and $1200^{\circ} \mathrm{C}$, is considered to be restricted to the upper $500-100 \mathrm{~m}$ of the water column (McBirney 1963; Jones 1969). If these lavas are komatiitic, the higher temperature of eruption thus implied $\left(1450^{\circ} \mathrm{C}\right.$ or higher, cf. Green et al. 1975; Shima and Naldrett 1975) may extend the depth range by $20 \%$. However, as the vesicularity of a lava is also controlled by hydrostatic pressure, the fact that parts of some lavas at Toivalanmäki consist of $>50 \%$ vesicle space may place an independent constraint on the depth of eruption.

The pyroxenite - vesicular lava - agglomerate mass presents more of a problem. Its emplacement appears to have disrupted the pillow lava - tuff pile, and it too, shed debris into the tuff-breccia. It would therefore appear to be an integral part of the volcanic edifice. Coarse pyroxenite is known to occur in the centre of certain komatiitic flows reported from several areas (cf. Arndt et al. 1979; Hynes \& Francis 1982), and so the pyroxenite of the Toivalanmäki association is tentatively interpreted as representing a late tholoid or lava dome, rising in the core of the pillow-tuff mound (Fig. 9 d). Structures like this grow from within, fed by material rising up a vent or lava tube, possibly representing residual liquid in the centre of a consolidated lava flow. Growth from within produces a finegrained skin, often vesiculate, that cools, is disrupted by expansion and sheds debris into a talus apron overridden by the expanding mass (cf. tholoids of the Lipari Islands, Rittmann 1962). Ultimately this process exposed the coarse pyroxenite core, which then contributed debris to the tuff-breccia (Fig. 9 e). Material injected into such a tholoid is highly viscous and it is suggested that here it constituted a crystal-mush of fractured pyroxene.

As the effusive activity died down the mound 

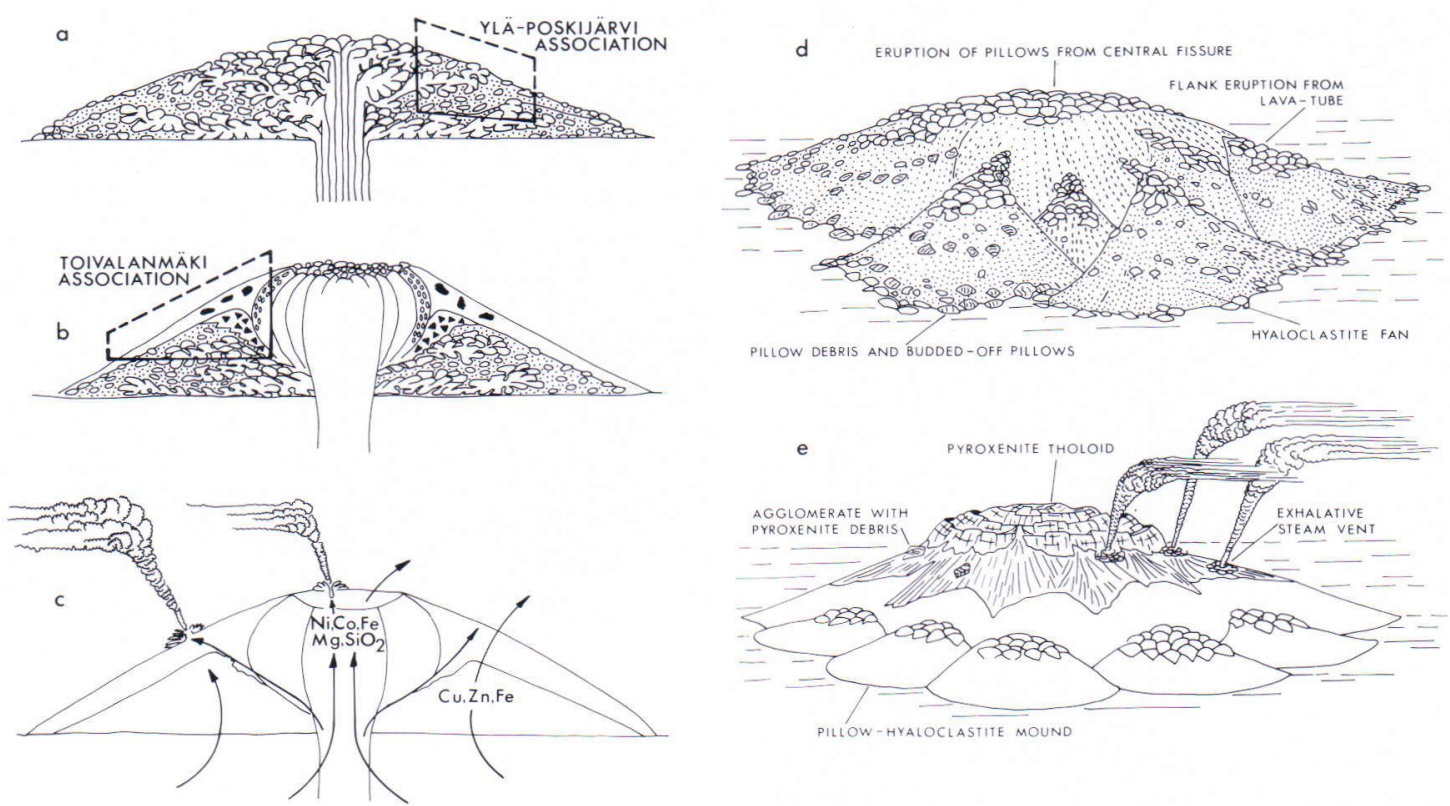

PILLOW DEBRIS AND BUDDED-OFF PILLOWS

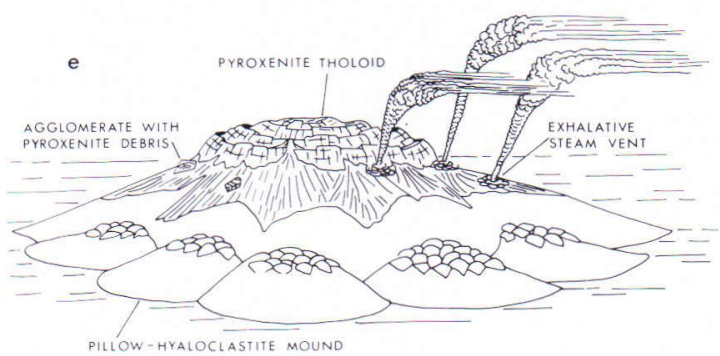

Fig. 9. Diagrammatic representation of pillow-tuff mound and submarine volcanic edifice. (a) Ylä-Poskijärvi association and its relationships formed during the early eruptive phase. (b) Toivalanmäki association developed during later stages, with the pyroxenite tholoid. (c) Late hydrothermal cooling and ore exhalation. (d) Early pillow-tuff mound. (e) Late development of the pyroxenite tholoid.

would become a site of intense hydrothermal activity driven by the residual heat of the lava pile (Fig. 9 c, e). Such hydrothermal solutions would radically alter some of the tuffs and pillow lavas, perhaps enriching them in alkalis and in elements such as $\mathrm{Mg}$ and $\mathrm{Sr}$ ( $c f$. Hutchinson et al. 1979; McGeehan and McLean 1980; Seyfried \& Mottl 1980). Other metals would be leached out (e.g. $\mathrm{Cu}, \mathrm{Zn}, \mathrm{Fe}$ and possibly $\mathrm{Ni}$ and $\mathrm{Co}$, Hutchinson et al. 1979; Franklin et al. 1980), and then precipitated from exhalative steam vents (Franchetean et al. 1979); the Ylä-Poskijärvi pillow lavas are considered to represent extremely leached material. Even hydrocarbons derived from the carbonaceous pelites (black schist) and redeposited as heavier, pyrogenic aromatic molecules in the lavas, now seen as carbon in several of the volcanogenic lithologies, may be involved in this hydrothermal activity (cf. Simoniet and Lonsdale 1982).
Shallow-water environment for eruption is inconsistent with volcanic rocks forming part of an ocean-floor assemblage, and with the edifice having built up from the abyssal plain. It is, however, strikingly similar to the shallow water environments of island arcs, some back-arc basins, and environments deduced using similar criteria in some greenstone belts ( $c f$. Dimroth et al. 1978; De Rosen-Spence et al. 1980; Imreh 1980; Jackson 1980; Okada 1980; Tarney \& Windley 1981; Bluck 1982).

\section{Deformation and fabric development}

\section{Ylä-Poskijärvi association}

The deformation and sequential development of fabric elements in the rocks of this associations has been described by Park and Bowes 

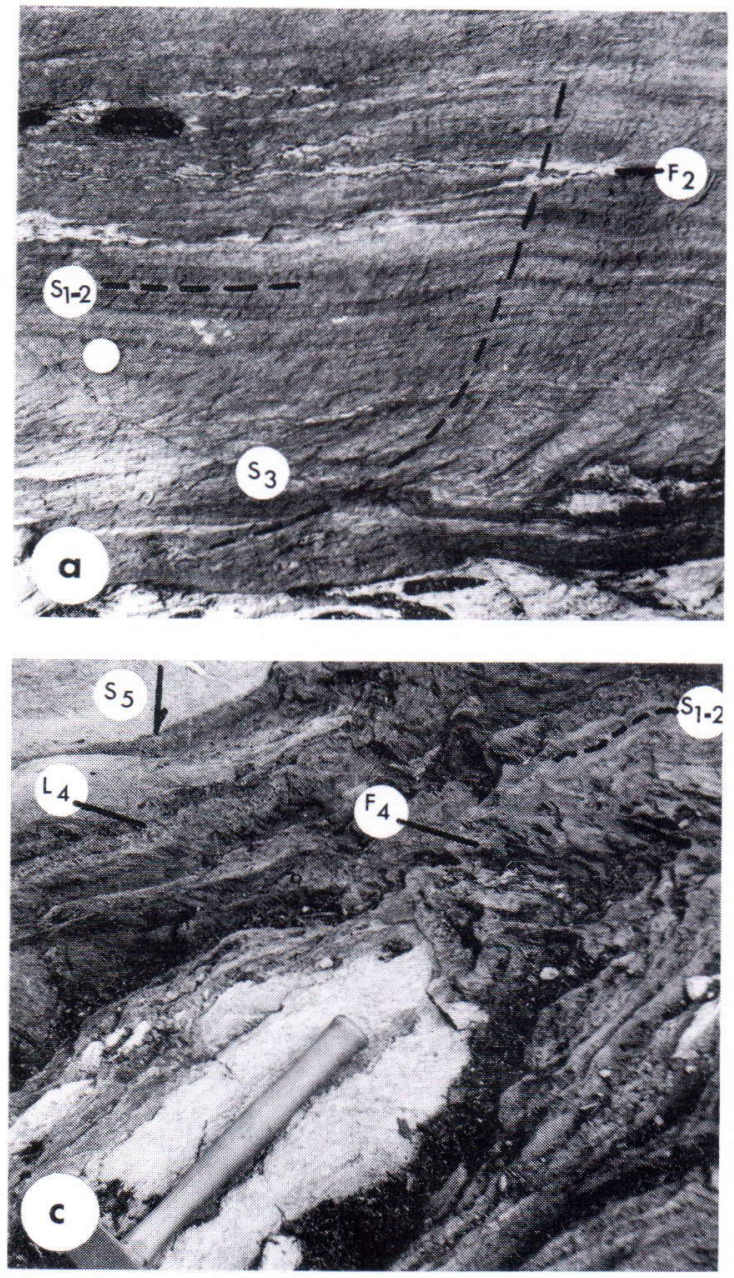

(1981). The following are significant points and only essential details will be recounted here.

1. The deformation observed here involves the progressive flattening of the pale pillows until axial ratios exceed $1: 1: 50$.

2. This was effected during two phases of deformation, with the folds $\left(\mathrm{F}_{1}, \mathrm{~F}_{2}\right)$ having axial planar fabrics $\left(\mathrm{S}_{1}, \mathrm{~S}_{2}\right)$ with consistent refolding and cross-cutting relationships developed in both pillows and matrix.

3. The largest increment of strain occurred during $\mathrm{D}_{2}$, when refolding and boudinage affected already moderately flattened pillows, $\mathrm{S}_{1}$ being deformed within boudin

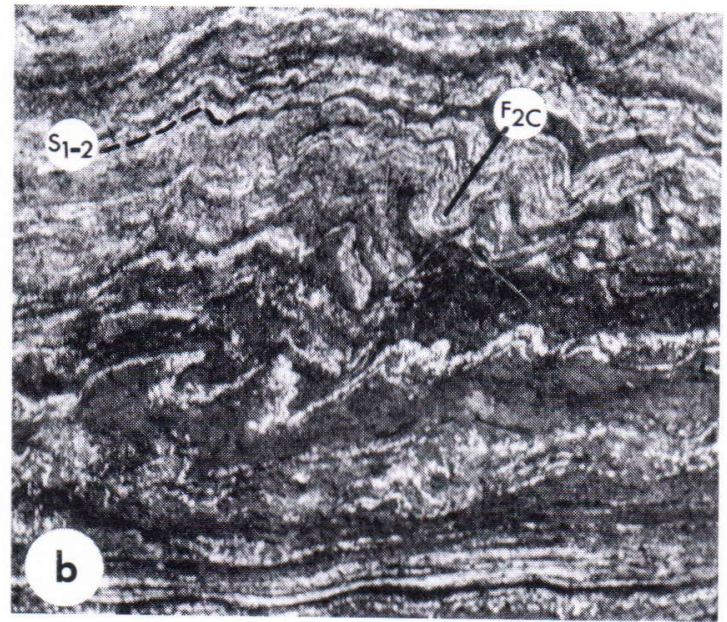

Fig. 10. Deformational fabrics. (a) Banded metatuff with composite $\mathrm{S}_{1-2}$ and tight $\mathrm{F}_{2}$ fold; $\mathrm{S}_{3}$ cleavage shows refraction through this layer; Ylä-Poskijärvi, coin $=2.2 \mathrm{~cm}$. (b) Banded metatuff with composite $\mathrm{S}_{1-2}$ fabric deformed by minor $\mathrm{F}_{2 \mathrm{C}}$ folds, Ylä-Poskijärvi; field of view $=80 \mathrm{~cm}$. (c) Composite $\mathrm{S}_{1-2}$ fabric in tuff matrix deformed by $\mathrm{F}_{4}$ crenulate folds, and cut by $\mathrm{S}_{4}$ cleavage. The white pillows carry $\mathrm{S}_{4}$ as a fracture. $\mathrm{L}_{4}$ is also developed in both lithologies. $\mathrm{S}_{5}$ is a quartz-filled fracture cleavage. Hammer handle = $30 \mathrm{~cm}$. Ylä-Poskijärvi.

necks by $\mathrm{F}_{2}$ scar folds (Park and Bowes 1981, figs. 3, 4, 5). Some $D_{1}$ boudinage is also evident.

4. $D_{2}$ strain was demonstrably heterogeneous, its strongest impact being localised close to the $\mathrm{D}_{2}$ thrust planes. Pillows, albeit flattened, boundinaged and folded, are still clearly recognisable within the thrust slices, but close to the thrusts the pillows are streaked out into subparallel units forming a banded amphibolite.

5. Fragmentation of the pillows by boudinage can be demonstrated as being a $\mathrm{D}_{2}$ event in which a consistent geometry related to that 
of $\mathrm{F}_{2}$ folds is maintained. This boudinage disrupts the pillow features, e.g. fine grained margins, and as such the pillows remain distinct even when greatly elongated (Park and Bowes 1981, figs. 2, 3, 4).

6. Subsequent phases of deformation (post- $\mathrm{D}_{2}$ ) had far less drastic effects, and the style of fabric development is governed by the dual physical properties (massive pillow - tuff matrix) which now form sub-parallel bands in the more deformed rock.

7. The duality of composition and mechanical properties exercises the single most important influence on the expression of mineral fabric. This duality has been noted from $D_{1}$ onwards in some rocks, but becomes general after $D_{2}$. The difference is most striking if a rock from the core zone of an imbricate slice is compared with one from the vicinity of a $\mathrm{D}_{2}$ thrust (Fig. $10 \mathrm{c}$; Park and Bowes 1981, fig. 2). Post- $\mathrm{D}_{2}$ fabrics define folds with axial planar cleavages in the tuff matrix, but they are expressed as regular fractures only in the little-deformed pillows. Indeed, the contrast in fabric expression between matrix and pillow is more dramatic than between the little deformed Ylä-Poskijärvi association and banded amphibolite. As flattening brings about the production of banded amphibolite, not only does the rock become more homogeneous petrographically, but the mechanical properties become less disparate (Fig. $10 \mathrm{c} c f$. Fig. 11). The style of fabric expression in the banded amphibolite is more comparable with the other layered lithologies at Losomäki. The massive deformed pillow units therefore do not carry $\mathrm{F}_{2 \mathrm{C}}, \mathrm{F}_{3}$ or $\mathrm{F}_{4}$ minor folds, whereas $\mathrm{S}_{2 \mathrm{C}}, \mathrm{S}_{3}, \mathrm{~S}_{4}$ and occasionally $\mathrm{S}_{5}$, form regular fractures (Fig. $10 \mathrm{c}$ ). In the more schistose rocks (primarily tuff) $\mathrm{F}_{2 \mathrm{C}}, \mathrm{F}_{3}, \mathrm{~F}_{4}$ folds and $\mathrm{S}_{2 \mathrm{C}}, \mathrm{S}_{3}$ and $\mathrm{S}_{4}$ cleavages are conspicuous; $\mathrm{S}_{3}$ and $\mathrm{S}_{4}$ are usually crenulation cleavages, and crenulation lineations $\left(\mathrm{L}_{3}, \mathrm{~L}_{4}\right)$, sometimes carrying a mineral growth, are widespread (Figs $10 \mathrm{~b}$, c, 11).

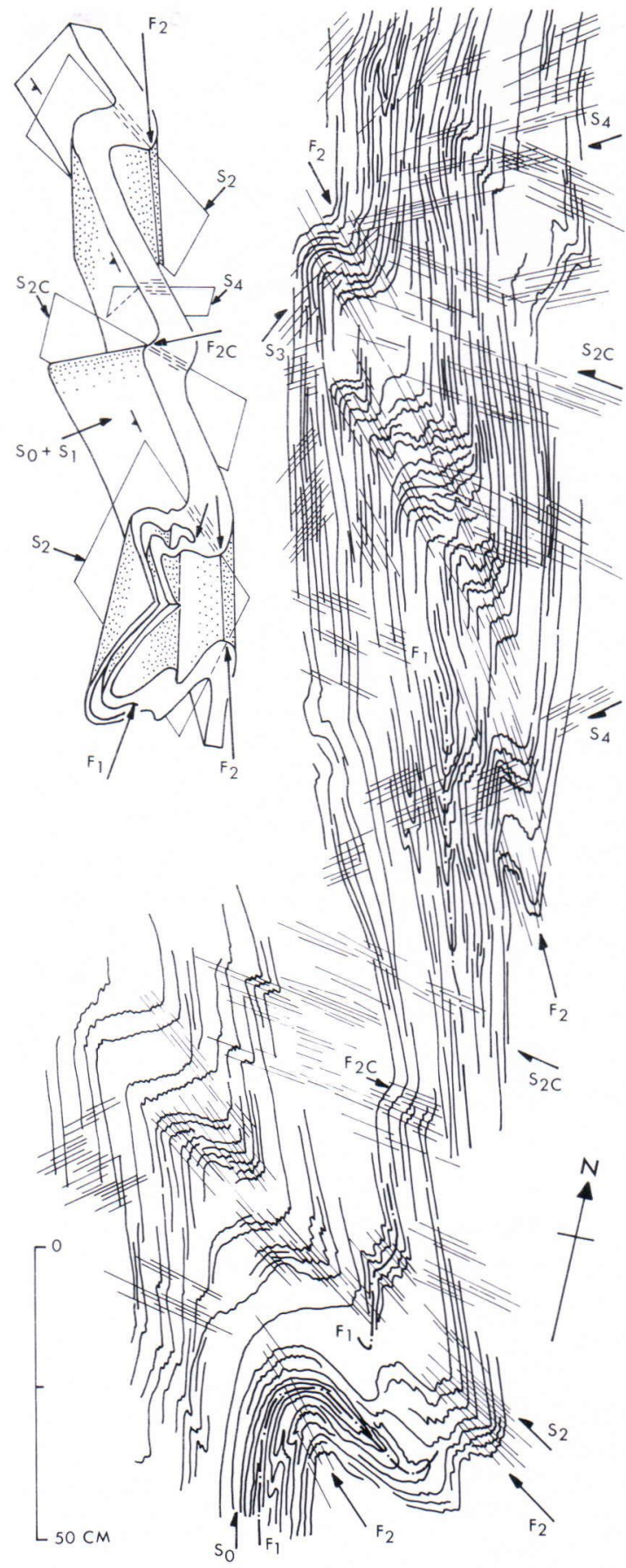

Fig. 11. Drawing of folds and fabric developed in banded metatuff with $\mathrm{S}_{0-1}$ composite banding deformed by $\mathrm{F}_{1}$ (intrafolial), $F_{2}$ and $F_{2 C}$ folds and cut by $S_{2}, S_{2 C}, S_{3}$ and $S_{4}$ fabrics. Inset is synoptic block diagram of structure, showing the geometrical relationships of folds and fabrics. Exploration trenchs, Ylä-Poskijärvi. 


\section{Toivalanmäki association}

Fabric development in this low strain enclave is sparse and cross-cutting relationships are equivocal. Two, occasionally three, well-spaced fracture sets occur in the tuff-breccia, offsetting clasts and matrix alike. One (apparently the earliest) which is correlated with $\mathrm{S}_{2}$ and has almost the same attitude as $\mathrm{S}_{2}$ in the adjacent mica schist, is approximately parallel to the $\mathrm{D}_{2}$ thrust in the overlying serpentinite and may be associated with some clast elongation. This fabric is cut by a vertical fracture running NE-SW, that is tentatively correlated with $\mathrm{S}_{4}$.

The effects of more intense deformation are restricted to narrow, well defined zones running through the tuff-breccia (Fig. 6). These zones, parallel to the $\mathrm{S}_{2}$ fabric in the tuff-breccia and the $\mathrm{D}_{2}$ thrusts above, consist of a porphyroblastic garnet-chlorite-amphibole tectonic schist (knotenschiefer) which contains flattened remnants of clasts in a strongly foliated chlorite matrix. The clast remnants are cut by veins filled with a coarse growth of amphibole, chlorite and garnet, crudely foliated in $\mathrm{S}_{2}$. The $\mathrm{S}_{2}$ fabric is occasionally crenulated. The crenulation define a N-S lineation which is cut by the spaced $\mathrm{S}_{4}$ fracture, and is correlated with $\mathrm{S}_{3}$ (Park 1983).

Where there is more general deformation the rock is a well-foliated, banded greenschist in which the banding reflects modal variation of amphibole, epidote and $\mathrm{Mg}$-chlorite. Where occasional pillow relics are seen (e.g. at Käärmemutka - Fig. 1) the banding is displaced around them. It is deformed by asymmetrical folds whose distinct axial planar foliation lies parallel to $S_{2}$ in the mica schist and the $D_{2}$ thrusts. Accordingly although no $F_{1}$ folds have been recognised the compositional banding is interpreted as $\mathrm{S}_{1}$ and the asymmetrical folds as $\mathrm{F}_{2}$, with axial planar $\mathrm{S}_{2}$. A $\mathrm{N}$-S-trending, vertical crenulation cleavage $\left(\mathrm{S}_{3}\right)$ is axial planar to open, upright folds plunging $\mathrm{S}\left(\mathrm{F}_{3}\right)$, and crenulated surfaces carry a pronounced linea- tion $\left(\mathrm{L}_{3}\right) . \mathrm{F}_{4}$ folds are seen plunging $\mathrm{SW}$ with an axial planar, vertical cleavage $\left(\mathrm{S}_{4}\right)$; crenulation $\left(\mathrm{L}_{4}\right)$ is strongly expressed in more schistose lithologies. This fabric sequence corresponds with that seen regionally in mica schists and other lithologies (Park 1983).

\section{Metamorphic mineral growths}

\section{Ylä-Poskijärvi association}

The diopside, plagioclase and tawmawite-spinel relics appear to be overgrown by a coarse, static growth of zoisite and amphibole (magnesiohornblende) in the least deformed pillow cores. The static growths are recrystallised during the $\mathrm{D}_{2}$ flattening to give rise to an anisotropic zoisite-amphibole fabric $\left(\mathrm{S}_{2}-\mathrm{M}_{2}\right)$. Whether the earlier assemblage is entirely $\mathrm{M}_{1}$, or whether the diopside, plagioclase and tawmawite-spinel relate to something earlier than $M_{1}$ has not been established.

Progressive flattening is accompanied by progressive reduction of grain-size reduction in the same assemblage. The $\mathrm{S}_{2}$ mineral fabric becomes progressively more anisotropic until in the high-strain lithology the fabric is essentially an amphibole-zoisite-epidote mylonite with porphyroblasts of zoisite. In the schistose matrix a pre- $\mathrm{S}_{2}$ banding $\left(\mathrm{S}_{1}\right)$ is defined by variations in epidote content in an amphibole-epidotechlorite schist. $\mathrm{S}_{2}$ lies essentially parallel to thin $\mathrm{S}_{1}$ banding, and the rock is dominated by the $\mathrm{M}_{2}$ mineral growth (amphibole-epidote). In the deformed, banded amphibolite, zoisiteamphibole bands alternate with amphibolechlorite \pm epidote bands. The late $\mathbf{M}_{2}$ amphibole which co-exists with epidote is more siliceous than the early $\left(\mathrm{M}_{1}\right)$ hornblende, and is generally actinolite $\left(\mathrm{M}_{2}\right)$.

Subsequent mineral growths include a chlorite growth in $\mathrm{S}_{2 C}$ and $\mathrm{S}_{3}$ in the greenschist derived from tuff. $\mathrm{L}_{4}$ is an amphibole (actinolite) growth, but $\mathrm{S}_{4}$ does not usually contain any planar mineral growth. An exception is where 
occasional $\mathrm{S}_{4}$ fractures cut the deformed pillow lavas and are dilatant. These dilatant fractures usually carry veins of actinolite that does not express a fabric.

\section{Toivalanmäki association}

The presence of a late, pervasive, static greenschist facies overprint means that the nature of early mineral growths must be elucidated entirely on the basis of relics. The lack of tectonic fabric-compounds the difficulties and the knotenschiefer is the only lithology for which a fabric-mineral growth sequence can be elucidated with any degree of confidence. This sequential development is based on the relationship of garnet growth to the syn- $\mathrm{D}_{2}$ veins cutting deformed clasts.

The garnet growth consists of three parts often seen in one porphyroblast, an inner core, optically homogenous and often opaque, an optically zoned rim and an optically homogenous overgrowth. Both core and rim are cryptically zoned, the core being a ugrandite-almandine, and the rim a pyralspite-grossular species. Andradite forms zones in both. The optically homogeneous overgrowth is seen in or adjacent to the syn- $D_{2}$ veins, where the zoned garnet euhedra are broken up. The optically homogeneous garnet-hornblende assemblage of the vein-fill is considered to be $\mathrm{M}_{2}$, making the zoned porphyroblasts $\mathrm{M}_{1}$. Whether the opaque cores of the porphyroblasts are also $\mathrm{M}_{1}$ is doubtful, they differ radically in composition and have a sharp boundary with the zoned rim. Other pre$\mathrm{M}_{2}-\mathrm{S}_{2}$ mineral relics include ore minerals (Timagnetite-haematite) that occur as euhedral inclusions in the zoned garnet rim, but not in the cores or in the pinite pseudomorphs after (?) cordierite. Some amphibole may also belong to $\mathrm{M}_{1}$.

Chlorite overgrows all the garnet, sometimes preserving the euhedral outline, or forming an irregular, coarse, static aggregate. Some amphibole (actinolite) also overgrows these garnets and a coarse, static chlorite fills the bulk of the non-foliated parts of the syn- $\mathrm{D}_{2}$ veins. Both appear to predate $\mathrm{S}_{3}$. No new mineral growth is apparent in $\mathrm{S}_{3}$, but away from Toivalanmäki itself a chlorite growth may be present in $\mathrm{S}_{4}$, and $\mathrm{L}_{4}$ is defined by an actinolite growth. The all-pervasive green-schist facies retrogression is considered to have begun during late $\mathrm{D}_{2}$.

\section{Rantala}

The amphibolite mass here carries a spaced amphibole foliation parallel to the foliation in the tectonised contact (where it is transposing). It is thus parallel to $S_{2}\left(D_{2}\right.$ thrusts) and is correlated on this basis. Within the mass, the $\mathrm{S}_{2}-\mathrm{M}_{2}$ amphibole fabric separates lithons carrying an earlier amphibole fabric $\left(S_{1}-M_{1}\right)$. The quartz veins running through the whole mass carry a rodding $\left(\mathrm{L}_{2}\right)$. No later fabrics or mineral growths have been observed. However, as this amphibolite has shared the early deformational history of the other lithological units, it is assumed to have shared their complete deformational history.

\section{Regional distribution of volcanogenic products}

Despite the effects of polyphase deformation and metamorphic reconstitution, the metavolcanic rocks remain a distinct and cognate suite. The mineralogical criteria outlined above become less reliable as deformation progresses, but the geochemical criteria remain valid. Where rocks of the Ylä-Poskijärvi association are present, mineralogy, though not as precisely diagnostic, remains distinctive.

Deformed and recrystallised metavolcanic rocks such as those seen at Losomäki have now been recognised at Riihilahti, where banded zoisite-amphibolites occasionally carry diopside (Fig. 3); banded epidote-chlorite amphibolites and chlorite-amphibole greenschist have been recorded in drillholes at Miihkali and between 

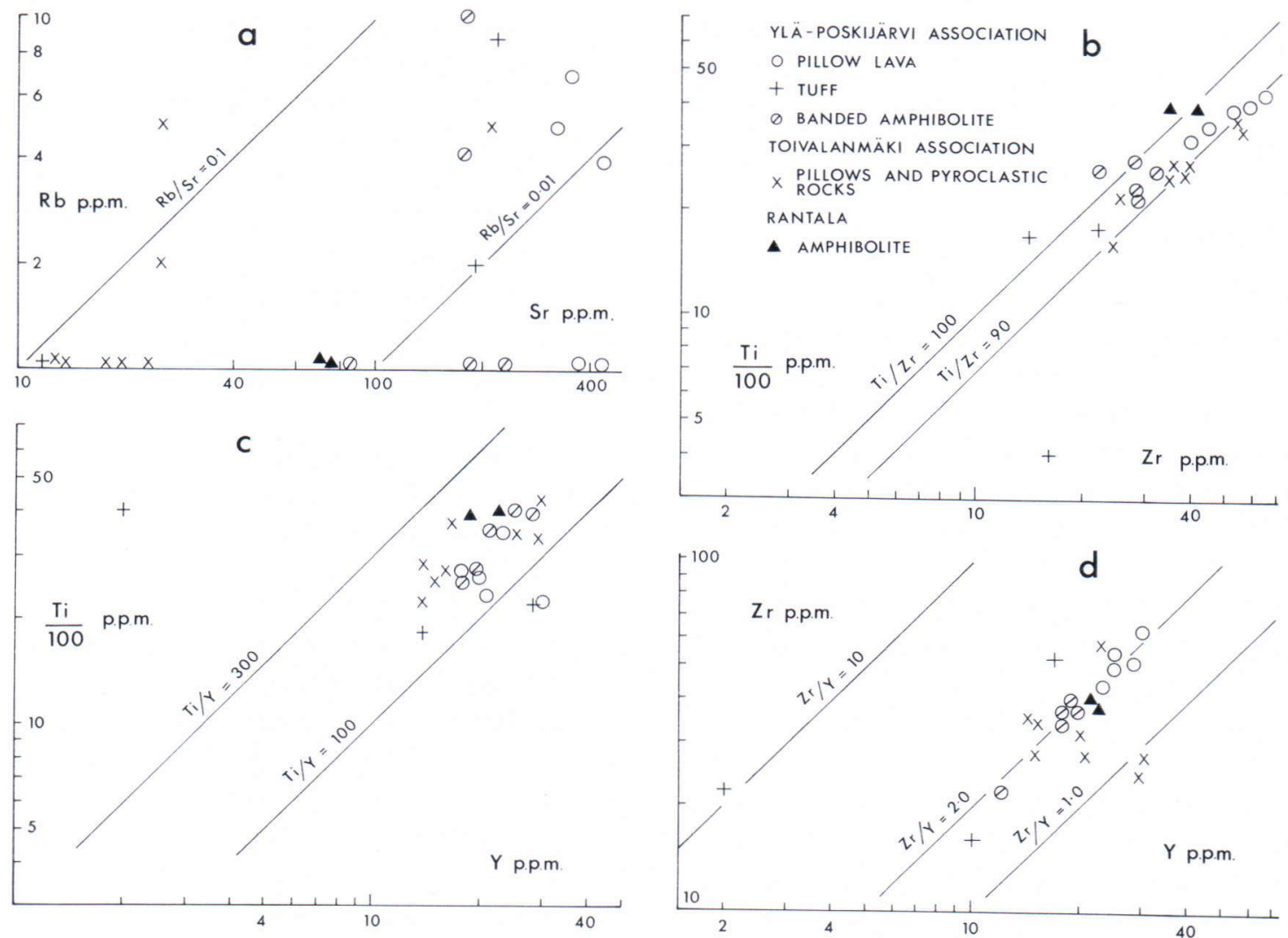

Fig. 12. Incompatible element ratio plots for metavolcanic rocks of the Losomäki area, all lithologies including banded amphibolites and Rantala amphibolite. (a) Rb v. Sr, (b) Ti/100 v. Zr, (c) Ti/100 v. Y, (d) Zr v. Y. Logarithmic scale used in each diagram; for data see Tables $1-3$.

Table 4. Incompatible element ratios.

\begin{tabular}{lcccc}
\hline & $\begin{array}{c}\text { Ylä-Poskijärvi } \\
\text { Pale pillows. }\end{array}$ & $\begin{array}{c}\text { Ylä-Poskijärvi } \\
\text { Tuff matrix. }\end{array}$ & $\begin{array}{c}\text { Banded } \\
\text { amphibolite. }\end{array}$ & $\begin{array}{c}\text { Rantala } \\
\text { amphibolite. }\end{array}$ \\
\hline $\mathrm{Rb} / \mathrm{Sr}$ & 0.00894 & 0.04467 & 0.0224 & 0.0766 \\
$\mathrm{Ba} / \mathrm{Sr}$ & $(0.00698)$ & $(0.02989)$ & $(0.0246)$ & $(0.0504)$ \\
& 0.143 & 0.395 & 0.646 & - \\
$\mathrm{K} / \mathrm{Rb}$ & $(0.146)$ & $(0.326)$ & $(0.789)$ & $(-)$ \\
& 600 & 870 & 1157.69 & 716.25 \\
$\mathrm{Y} / \mathrm{Ce}$ & $(120)$ & $(180)$ & $(520.29)$ & $(294.02)$ \\
& 1.719 & 0.532 & 1.215 & 0.503 \\
$\mathrm{Zr} / \mathrm{Y}$ & $(0.478)$ & $(0.285)$ & $(0.211)$ & $(0.257)$ \\
& 2.125 & $(4.649$ & 1.928 & $(0.628$ \\
$\mathrm{Ti} / \mathrm{Zr}$ & $(0.237)$ & 72.77 & $77.85)$ & $(0.504)$ \\
& 70.51 & $(6.53)$ & $(5.152)$ & 77.19 \\
$\mathrm{Ti} / \mathrm{Y}$ & $(6.18)$ & 389.21 & 149.60 & $(22.27)$ \\
& 148.94 & $(291.78)$ & $(13.15)$ & 125.88 \\
& $(13.61)$ & & & $(56.76)$ \\
\hline
\end{tabular}

Numbers in parentheses are for one standard deviation from the mean. Figures quoted are the mean of data given in Tables $1-3$. 

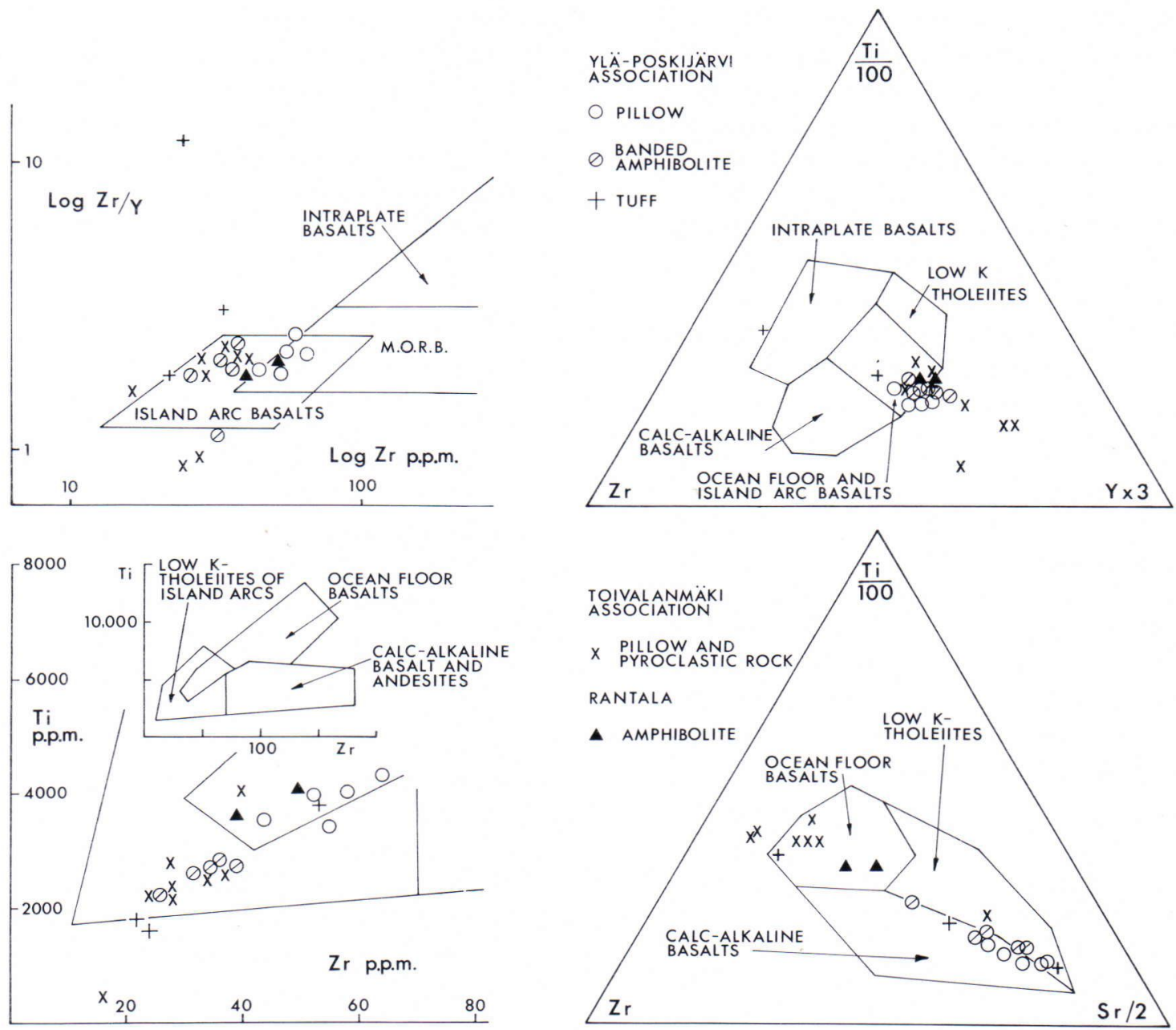

Fig. 13. Incompatible element discriminant function diagrams for the Losomäki metavolcanic rocks. (a) $\mathrm{Zr} / \mathrm{Y}$ v. $\mathrm{Zr}$ diagram for island arc, M.O.R.B. and intraplate basalts (Pearce and Norry 1979). (b) Ti v. Zr plot for all basalts (Pearce and Cann 1973). (c) Ti/100 v. Zr v. Y $\times 3$ plot for all basalts (Pearce and Cann 1973). (d) Ti/100 v. Zr v. Sr/2 plot; the data points define a Sr enrichment-depletion vector (Pearce and Cann 1973).

Outokumpu and Polvijärvi (Fig. 3). The belt between Polvijärvi and Savonranta is the only outcrop of Outokumpu assemblage where such rocks have not been recorded. Other unusual lithologies that may also have had a volcanogenic or hypabyssal protolith include a porphyroblastic amphibolite at Miihkali and some »barren skarns» at Louhilampi.

With the exception of the porphyroblastic amphibolite at Miihkali these metavolcanic rocks appear to define a cognate suite and their distribution appears to define a volcanic province almost co-terminous with the outcrop of the Outokumpu nappe, though they are not distributed evenly through it.

\section{Svecokarelian geotectonic significance}

Like the metasedimentary rocks of the Svecokarelian cover sequence (in both allochthon and 
autochthon), the metavolcanic rocks share a complete polyphase fabric development history. They relate to a phase of early history in the source area of the Outokumpu nappe, and this impinges directly on genetic models for the $\mathrm{Ou}$ tokumpu assemblage. Several models have been proposed which share an ophiolitic (ocean floor) analogy ( $c f$. Campbell 1978; Bowes 1980; Bowes and Gaál 1981; Koistinen 1981). However, the deduced environment of eruption for the volcanic rocks of the Losomäki area (and by inference the rest of the volcanic province) precludes a deep water origin.

An independent assessment of geotectonic environment is possible using the incompatible element ratios (viz: $\mathrm{Ti} / \mathrm{Zr}, \mathrm{Zr} / \mathrm{Y}$ and $\mathrm{Ti} / \mathrm{Y}$ ), in the manner formulated by Pearce and Cann (1975) and Pearce and Norry (1980). Some doubt has been cast on the validity of this approach for altered and metamorphosed basic or mafic rocks ( $c f$. Jelínek et al. 1979; McGeehan and McLean 1981; Beswick 1982) because of possible unwarranted assumptions regarding

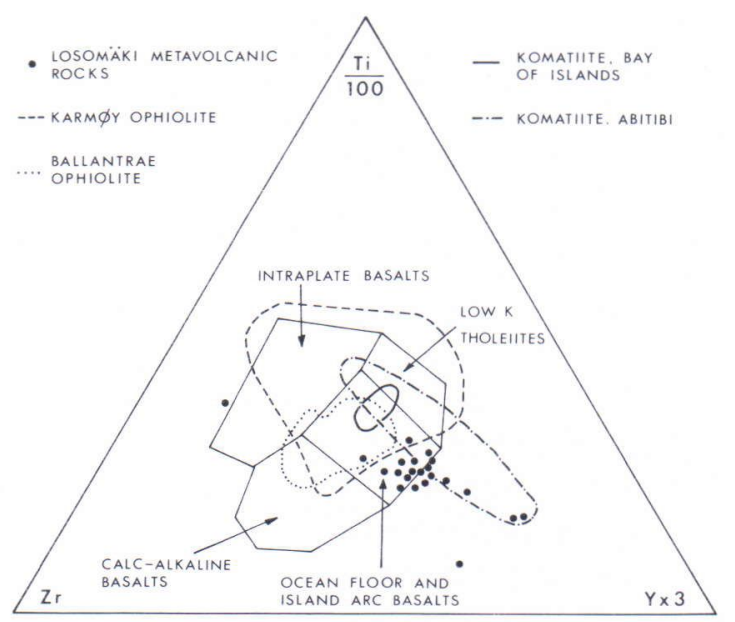

Fig. 14. Losomäki metavolcanic rocks compared with data from other shallow water basaltic provinces: komatiites (basaltic) from the Bay of Islands (Gale 1973), Archaean komatiites largely from Abitibi, Ontario (Nesbitt and Sun 1976), tuff-basalt-greenstone complex, Karmøy ophiolite, Norway (Furnes et al. 1980) and the Ballantrae ophiolite, SW Scotland (Jelínek et al. 1980). the supposed immobility of the large ion lithophile elements in rocks that reacted with seawater and initially contained a big fraction of glass. However, with sufficient independent constraints relating to element ratio change, the method is arguably valid even in metamorphosed volcanic rocks ( $c f$. Winchester and Floyd 1976, 1977).

Given the way the Ti-Zr-Y ratios remain consistent in these rocks even when severely deformed and modified, data have been plotted on the $\mathrm{Ti} / 100$ vs $\mathrm{Zr}$ vs $\mathrm{Y} \times 3$, Ti vs $\mathrm{Zr}$ and $\mathrm{Zr}$ vs $\mathrm{Zr} / \mathrm{Y}$ discriminant diagrams (Fig. 13; $c f$. Pearce and Cann 1973; Pearce and Norry 1979). These plots shown some degree of consistency, in that in all cases the data points fall into the field for island-arc tholeiites or where the fields overlap, that for mid-ocean-ridge basalt (MORB). In order to illustrate the effects of alteration of element ratios, data from the same rocks are plotted onto the $\mathrm{Ti} / 100$ vs $\mathrm{Zr}$ vs $\mathrm{Sr} \times$ 2 diagram (Fig. $13 \mathrm{~d}$; $c f$. Pearce and Cann 1975), having already ascertained that $\mathrm{Sr}$ is erratically distributed in these rocks ( $c f$. $\mathrm{Rb} / \mathrm{Sr}$ ratio - Fig. 12 a; Table 4). The result is consistent with $\mathrm{Sr}$ mobility compared with a consistent $\mathrm{Ti} / \mathrm{Zr}$ ratio; the scattered points define an $\mathrm{Sr}$ vector throughout the basalt fields.

The conclusions drawn earlier regarding geotectonic environment are further reinforced by comparing the incompatible element data with those of Archaean greenstones (Abitibi Nesbitt and Sun 1976) and ophiolite complexes containing island arc or back-arc basin components (Bay of Islands, Ballantrae and Karmøy - cf. Fig. 14; Gale 1973; Jelínek et al. 1980; Furnes et al. 1980). Not only are the environments of eruption very similar, but the discriminant function diagrams do not permit any distinction to be made between island-arc material and Archaean greenstone belts. To which of these two environments the volcanic rocks of the Outokumpu assemblage have an affinity, or the greater affinity, has yet to be established. 

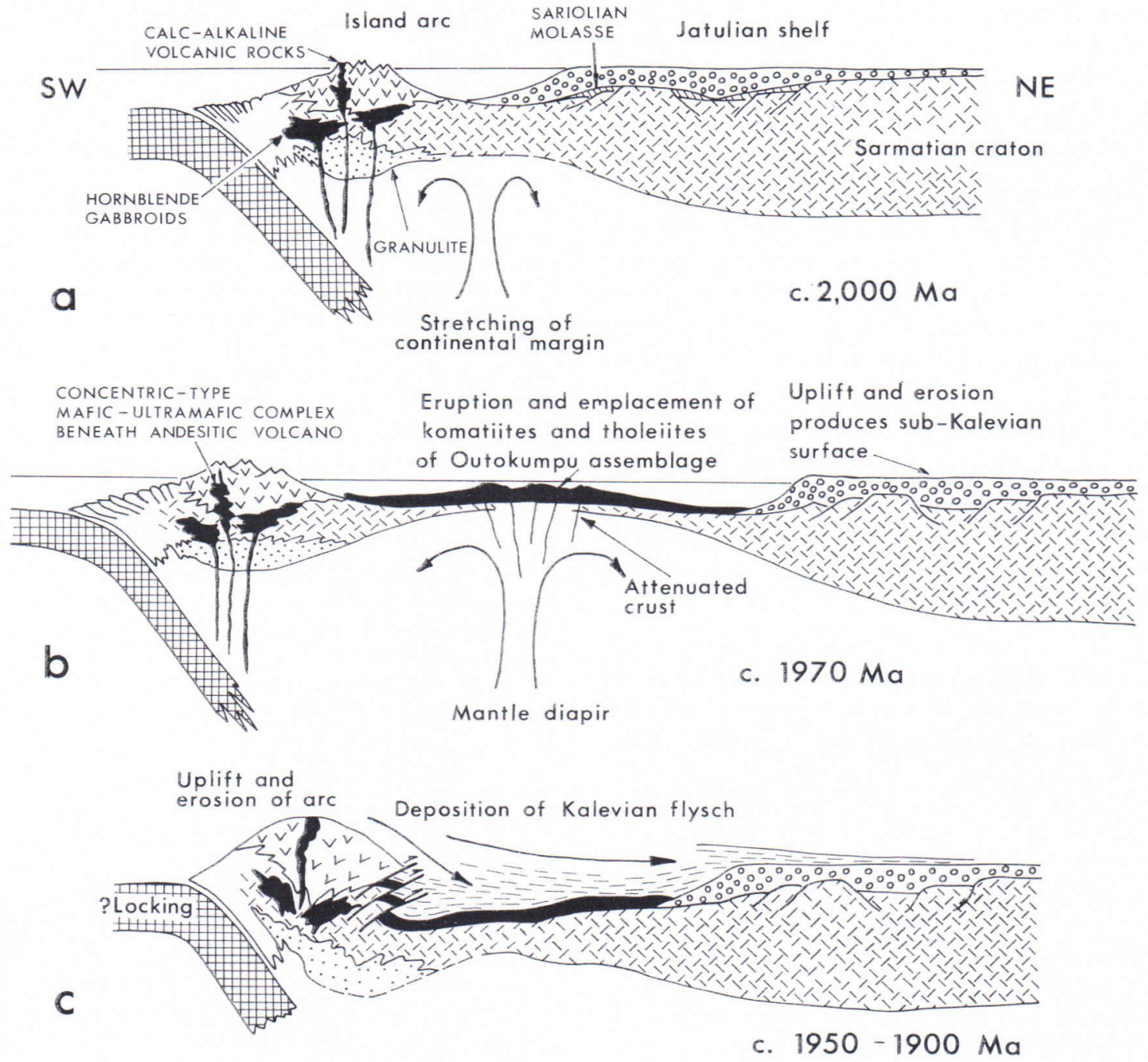

Fig. 15. Schematic reconstruction of the tectonic setting of the Outokumpu assemblage during the early stages of Svecokarelian tectonism. c. 2000-1950 Ma. (a) Subduction beneath an island-arc marginal to the Sarmatian continent accompanied by the initiation of crustal stretching over a mantle diapir. (b) Attenuation of continental crust in the back-arc accompanied by eruption of basaltic, Mg-basaltic or even komatiitic tholeiites. Mantle diapir gives rise to uplift producing a shallow water eruptive environment. Uplift of the continental margin may be responsible for the sub-Kalevian unconformity (c. $1970 \mathrm{Ma}$ ). (c) Thermal decay of the mantle diapir and/or locking of the subduction zone bring about uplift of the island-arc and subsidence of the back-arc basin. Erosion of the island-arc produces the Kalevian flysch deposited in the back-arc. (Subsequently further compression initiates the decollement of the supracrustal pile in the back-arc basin from its basement and the back arc basin sequence is obducted onto the continental margin as the Outokumpu nappe before c. $1900 \mathrm{Ma}$.)

\section{Conclusions}

The main conclusions drawn from this study are as follows.
1. The Outokumpu assemblage contains a volumetrically significant and morphologically diverse suite of volcanogenic rocks. These include pillow lavas, vesicular lava, tuffs, 
tuff-breccia, agglomerate and pyroxenite.

2. A shallow water environment of eruption and deposition with the production of hyaloclastites is deduced.

3. Original morphological characteristics have been recognised only in isolated low strain enclaves, but even where highly deformed and after metamorphic reconstitution a set of geochemical and mineralogical criteria can be defined which allow such rocks to be recognised throughout the Outokumpu district.

4. Given the results of recent studies on modern sea-floor exhalative centres the recognition of this volcanic province in the Outokumpu mining district has important implications for genetic modelling and further exploration.

5. Development in an island arc geotectonic environment is suggested. Given the early Proterozoic age of this assemblage, this could have important implications for plate tectonic interpretations of contemporaneous mobile belts and for genetic models for Archaean greenstone belts.

Acknowledgements. Professor D. R. Bowes supervised this work and made many improvements and suggestions to the draft manuscript. The co-operation of Myllykoski Oy is acknowledged with thanks, particularly the staff of the Exploration Department, Luikonlahti mine; F. Björnberg and P. Huopanniemi gave permission to examine exploration trenches, borehole cores and geophysical maps. Tapio Salaterä introduced me to the Losomäki district and provided much lively discussion in the field. Risto Virkkunen (Åbo Akademi) provided much stimulating discussion and a free exchange of ideas in the field. The Exploration Department of Outokumpu Oy provided logistical support during fieldwork.

I thank Teuvo and Rauha Hiltunen for their unstinting hospitality. Dr. C. Farrow (Glasgow) gave me tuition and advice in the use of the XRF and electron microprobe facilities. The skill of D. Maclean and Mrs. S. Hall, who printed the photographs and drafted the diagrams respectively, is greatly appreciated.

This research was carried out during the tenure of a UK Natural Environment Research Council grant, receipt of which is gratefully acknowledged.

\section{References}

Arndt, N. T. \& Brooks, C., 1980. Penrose conference on komatiites. Geology 8, 155-56.

-, Francis, D. \& Hynes, A. J., 1979. The field characteristics and petrology of Archaean and Proterozoic komatiites. Canad. Mineral. 17, 147-63.

—, \& Nesbitt, R. W., 1982. Geochemistry of Munro Township basalts. In: Arndt, N. T. and Nisbet, E. G. $(e d s)$ Komatiites. Allen and Unwin, London, 309-29.

Beswick, A. E., 1982. Some geochemical aspects of alteration, and genetic relations in komatiitic suites. In: Arndt, N. T. and Nisbet, E. G. (eds) Komatiites. Allen and Unwin, London, 283-308.

Bluck, B. J., 1982. Hyalotuff deltaic deposits in the Ballantrae ophiolite of SW Scotland: evidence for crustal position of the lava sequence. Trans. R. Soc. Edinburgh Earth Sci. 72, 217-28.

Bochert, H., 1954. Kritische Bemerkungen zu zwei neuen Arbeiten über Outokumpu, Finnland. Zeitschr. Erzberg. Metall. 7, 82-4.

Bowes, D. R., 1980. Correlation in the Svecokarelides and a crustal model. In: Mitrofanov, F. P. (ed.) Principles and criteria of subdivision of Precambrian in mobile zones. Nauka, Leningrad, 294-303.

—, \& Gaál, G., 1981. Precambrian record of the eastern North Atlantic borderlands. Mem. Canad. Soc. Pet. Geol. 7, 31-55,

Campbell, D. S., 1978. Structural and metamorphic studies in the Svecokarelides, Tampere, Finland. Unpubl. Ph.D. Thesis, Univ. of Glasgow.

De Rosen-Spence, A. F.; Provost, G.; Dimroth, E.; Gochnauer, K. \& Owen, V., 1980. Archaean sub-aqueous felsic flows, Rouyn-Noranda, Quebec, Canada, and their Quaternary equivalents. Precambrian Res. 12, 43-77.

Dimroth, E.; Cousineau, P.; Leduc, M. \& Sanschagrin, Y., 1978. Structure and organisation of Archaean subaqueous basalt flows, Rouyn-Noranda area, Quebec, Canada. Can. J. Earth Sci. 15, 902-18.

Ehlers, C., 1978. Gravity tectonics and folding around a basic volcanic centre in the Kumlinge area, S.W. Finland. Bull. Geol. Surv. Finland 295, 43 p. 
Eskola, P., 1933. On the chrome minerals of Outokumpu. Bull. Comm. Geol. Finlande 103, 26-44.

Francheteau, J. et al., 1979. Massive deep-sea sulphide ore deposits discovered on the East Pacific Rise. Nature 277, 523-28.

Franklin, J. M., Lydon, J. W. \& Sangster, D. F., 1981. Volcanic associated massive sulphide deposits. Econ. Geol. 75th Anniversary Vol. 485-627.

Furnes, H.; Sturt, B. A. \& Griffin, W. L., 1980. Trace element geochemistry of metabasalts from the Karmøy ophiolite, southwest Norwegian Caledonides. Earth Planet. Sci. Lett. 50, 75-91.

Gaál, G., 1980. Geological setting and intrusion tectonics of the Kotalähti nickel-copper deposit, Finland. Bull. Geol. Soc. Finland 52, 101-28.

Gale, G. H., 1973. Palaeozoic basaltic komatiites and ocean-floor basalts from NE Newfoundland. Earth Planet. Sci. Lett. 18, 22-8.

Gélinas, L.; Mellinger, $M \&$ Trudel, P., 1982. Archaean mafic metavolcanics from the Rouyn-Noranda district, Abitibi Greenstone Belt, Quebec. 1 Mobility of major elements. Can J. Earth Sci. 19, 2258-75.

Green, D. H.; Nicholls, I. A.; Viljeon, M. \& Viljeon, R., 1975. Experimental demonstration of the existence of peridotitic liquids in earliest Archaean magmatism. Geology 3, 11-4.

Huhma, A., 1975. Precambrian rocks of the Outokumpu, Polvijärvi and Sivakkavaara map sheets. 1:100,000 (Summary in English). Geologinen Tutkimuslaitos, Espoo, $131 \mathrm{p}$.

Hutchinson, R. W.; Fyfe, W. S. \& Kerrich, R., 1980. Deep fluid penetration and ore deposition. Minerals Sci. Engng. 12 (3), 107-20.

Hyde, R. S., 1980. Sedimentary facies in the Archaean Timiskaming Group and their tectonic implications, Abitibi Greenstone Belt, north eastern Ontario, Canada. Precambrian Res. 12, 161-95.

Hynes, A. \& Francis, D., 1982. Komatiitic basalts in the Cape Smith fold belt, New Quebec, Canada. In: Arndt, N. T. and Nisbet, E. G. (eds.) Komatiites. Allen and Unwin, London, 159-70.

Imreh, L., 1980. Variations morphologiques des coulées méta-ultramafiques komatiitiques du sillon Archéen de la motte-vassan, Abitibi-est, Québec. Precambrian Res. $12,3-30$.

Jackson, M. C., 1980. Stratigraphy and flow morphology of Archaean tholeiites, northeastern Ontario. Precambrian Res. 12, 31-41.

Jelínek, E.; Soucek, J.; Bluck, B. J.; Bowes, D. R. \& Treolar, $P$. J., 1980. Nature and significance of beerbachites in the Ballantrae ophiolite, S.W. Scotland. Trans. R. Soc. Edinburgh Earth Sci. 71, 159-79.

Jones, J. G., 1969. Pillows lavas as depth indicators. Am. J. Sci. 267, 181-95.
Koistinen, T. J., 1981. Structural evolution of an early Proterozoic strata-bound $\mathrm{Cu}-\mathrm{Co}-\mathrm{Zn}$ deposit, Outokumpu, Finland. Trans. R. Soc. Edinburgh Earth Sci. 72, 115 -58 .

Leake, B. E., 1978. (ed.) Nomenclature of amphiboles. Canad. Mineral. 16, 501-20.

Luddens, J.; Gélinas, L. \& Trudel, P., 1982. Archaean mafic metavolcanics fron the Rouyn-Noranda district, Quebec. 2. Mobility of trace elements and petrogenetic constraints. Can. J. Earth Sci. 19, 2276-87.

McBirney, A. R., 1963. Factors governing the nature of submarine volcanism. Bull. Volcanologique 26, 455 -69 .

McGeehan, P. J. \& McLean, W. H., 1980. An Archaean sub-seafloor geothermal system, 'calc-alkali' trends, and massive sulphide genesis. Nature 286, 767-71.

Mäkelä, M., 1974. A study of sulphur isotopes in the Outokumpu ore deposits. Bull. Geol. Surv. Finland 267, 45 p.

Moore, J. G., 1975. Mechanism of formation of pillow lava. Am. Sci. 63, 269-77.

Mutanen, T., 1976. Komatiites and komatiite provinces in Finland. Geologi 28, 40-56.

Myers, J. S., 1978. Formation of banded gneisses by deformation of igneous rocks. Precambrian Res. 6, 43-64.

Nesbitt, R. W. \& Sun, S.-S., 1976. Geochemistry of Archaean spinifex-textured peridotites and magnesian and low-magnesian tholeiites. Earth Planet. Sci. Lett. $31,433-44$.

Okada, H., 1980. Sedimentary environments on and around island arcs: an example of the Japan Trench area. Precambrian Res. 12, 115-39.

Park, A. F., 1983. The origin and tectonic setting of serpentinites and related rocks in the Outokumpu assemblage of the Svecokarelides, eastern Finland. Unpubl. Ph.D. Thesis, Univ. of Glasgow.

Park, A. F. \& Bowes, D. R., 1981. Metamorphosed and deformed pillows from Losomäki: evidence of subaqueous volcanism in the Outokumpu association, eastern Finland. Bull. Geol. Soc. Finland 53-2, 135-45.

Pearce, J. A. \& Cann, J. R., 1973. Tectonic setting of basic volcanic rocks determined using trace element analyses. Earth Planet. Sci. Lett. 19, 290-300.

-, \& Norry, M. J., 1979. Petrogenetic implications of Ti, $\mathrm{Zr}, \mathrm{Y}$ and $\mathrm{Nb}$ variations in volcanic rocks. Contrib. Mineral. Petrol. 69, 33-47.

Rittmann, A., 1962. Volcanoes and their activity. Wiley, New York.

Seyfried, W. E. \& Mottl, M. J., 1982. Hydrothermal alteration of basalt by seawater under seawater-dominated conditions. Geochem. Cosmochim. Acta 46, 985-1002.

Shima, H. \& Naldrett, A. J., 1975. Solubility of sulphur in an ultramafic melt and the relevance of the system Fe-SO. Econ. Geol. 70, 960-67. 
Simoneit, B. R. T. \& Lonsdale, P. F., 1982. Hydrothermal petroleum in mineralised mounds at the seabed of Guaymas Basin. Nature 295, 198-202.

Tarney, J. \& Windley, B. F., 1981. Marginal basins through geological time. Phil. Trans. R. Soc. London A, 301, 217-32.
Väyrynen, $H ., 1939$. On the geology and tectonics of the Outokumpu ore field and region. Bull. Comm. Geol. Finland 124, $91 \mathrm{p}$.

Wegmann, C. E., 1982. Über die Tektonik der jüngeren Faltung in Ostfinniand. Fennia 50(16), 1-22.

Manuscript received, June 6, 1983. 